\title{
Study of Ce/Pr ratio in ceria-praseodymia catalysts for soot combustion under different atmospheres
}

\author{
N. Guillén-Hurtado, J. Giménez-Mañogil, J.C. Martínez-Munuera, A. Bueno-López and A. García- \\ García * \\ MCMA Group, Department of Inorganic Chemistry and Institute of Materials, University of \\ Alicante, Ap.99, E-03080 Alicante, Spain.
}

\begin{abstract}
The effect of $\mathrm{Ce} / \mathrm{Pr}$ ratio on ceria-praseodymia on structural and surface properties is studied. The catalytic activity towards soot combustion under $\mathrm{NOx} / \mathrm{O}_{2}$ and $\mathrm{O}_{2} / \mathrm{N}_{2}$ atmospheres is also evaluated, together with the $\mathrm{NO}$ oxidation activity to $\mathrm{NO}_{2} \cdot \mathrm{Ce}_{\mathrm{x}} \mathrm{Pr}_{1-\mathrm{x}} \mathrm{O}_{2-\delta}$ compositions $(\mathrm{x}=0.8,0.5$ and 0.2 ) have been prepared along with ceria and praseodymia. Catalysts were prepared by coprecipitation. The $\mathrm{Ce}_{0.5} \mathrm{Pr}_{0.5} \mathrm{O}_{2-\delta}$ composition, was also prepared by nitrate calcination. Ceriapraseodymia mixed oxides yield reduction profiles shifted to lower temperatures, higher NO oxidation activities to $\mathrm{NO}_{2}$ and improved catalytic activities for soot combustion with respect to pure ceria. $\mathrm{Ce}_{0.5} \mathrm{Pr}_{0.5} \mathrm{O}_{2-\delta}$ was the most active one. Under $\mathrm{NOx} / \mathrm{O}_{2}$, it has greater soot combustion activity if it is prepared by nitrate calcination. However, under $\mathrm{O}_{2} / \mathrm{N}_{2}$, the co-precipitation method is more favorable because of the better dopant insertion achieved in the ceria lattice, which seems to lead better oxygen mobility on the surface and in the bulk oxide.
\end{abstract}

Keywords: Ceria-praseodymia; NO oxidation; soot combustion; active oxygen.

*Corresponding author. Tel.: +34 965909419; e-mail: a.garcia@ua.es

Fax: +34 965903454 


\section{Introduction}

Diesel engines are commonly used in light-duty and heavy vehicles, and their utilization has increased in the last years [1]; however, diesel exhaust emissions are not completely controlled yet, in terms of harmful substances for the environment and human health. In fact, legislations are becoming stricter regarding the emission levels permitted, especially for nitrogen oxides (NOx) and particulate matter (soot) [2-4]. Therefore, new strategies were and are being developed, in order to achieve the abatement of these pollutants [5-10].

The use of ceria as a key component of three-way catalysts (TWCs) started to be important in automotive after-treatment technologies in the 1970s in gasoline engines [11]. The scientific interest on these ceria-based materials promoted their use in several industrial applications [12]. Thus, development of ceria-based materials has increased in the present years and they are still relevant nowadays. These materials have been widely studied and implemented in several diesel exhaust after-treatment devices, due to their interesting properties. However, pure ceria has some drawbacks, such as thermal sintering and deactivation of the redox pair $\mathrm{Ce}^{4+} / \mathrm{Ce}^{3+}$, resulting in a decrease of its oxygen storage/release capacity (OSC) and also a decrease in its catalytic activity [13-15]. Therefore, over the last years, much effort has been invested in research to improve the redox and catalytic properties of ceria by doping it with other cations [16-19], with the aim of both creating more oxygen vacancies to allow the migration of oxide anions through the lattice $[20,21]$ and improving its thermal sintering resistance [22, 23].

In this respect, it is well described in the literature the ceria doping with aliovalent cations, such as $\mathrm{Eu}^{3+}$ [24], $\mathrm{La}^{3+}$ [25], $\mathrm{Gd}^{3+}$ or $\mathrm{Sm}^{3+}$ [26], as well as isovalent cations, such as $\mathrm{Zr}^{4+}$ [23], $\mathrm{Hf}^{4+}$ [27] and $\mathrm{Ti}^{4+}[18]$ as the most studies ones. On the one hand, incorporating an aliovalent cation into the ceria structure generates anionic oxygen vacancies by charge compensation on the final oxide [29]. On the other hand, doping with isovalent cations, such as $\mathrm{Zr}^{4+}[12,16,21,23]$, also leads to an improvement in the redox properties of ceria [30,31]. Thus, the partial replacement of $\mathrm{Ce}^{4+}$ by $\mathrm{Zr}^{4+}$ cations entails a deformation in the $\mathrm{CeO}_{2}$ network due to the lower ionic radius of $\mathrm{Zr}^{4+}$, deriving to an improvement in the oxygen storage capacity of the ceria [32]. A third possibility is to obtain a mixture of these two effects by doping ceria with lanthanide elements with variable oxidation states. In such case, terbium [33] and praseodymium [34-39] are the most studied ones. 
The addition of praseodymium to the ceria lattice increases both the oxygen desorption at low temperatures and the creation of oxygen vacancies compared to pure ceria. The first of these two effects is devoted to the lower binding energy of oxygen anions in ceria-praseodymium mixed oxides [38]; and the second effect is due to the existence of $\mathrm{Pr}^{3+}$ cations, since it is known that the reduction potential of $\mathrm{Pr}^{4+} / \mathrm{Pr}^{3+}$ is higher than that of $\mathrm{Ce}^{4+} / \mathrm{Ce}^{3+}$ [40], being these values in aqueous media of 3.2 $\mathrm{eV}$ and $1.72 \mathrm{eV}$, respectively [41].

Thus, while the zirconium dopant introduces a limited number of oxygen vacancies into the ceria structure $[42,43]$, the praseodymium dopant leads to a larger population of anionic vacancies with improved mobility [44]. These features lead to redox properties in the ceria-praseodymium system that are superior to those of other mixed oxides studied [35, 38, 45], especially in low character reducing atmospheres. In this case, this aspect becomes interesting for applications where oxidizing atmospheres $\left(\mathrm{O}_{2}\right.$ and/or $\left.\mathrm{NOx} / \mathrm{O}_{2}\right)$ are involved.

In this sense, many authors have pointed out that the reducibility of these oxides exhibit a low dependence with the sample surface [46, 47], in addition to an extremely rapid response in the oxygen exchange with the atmosphere, even when the environmental conditions slightly change. This makes the ceria-praseodymium mixed oxides a promising system for any type of reaction involving oxygen exchange [38].

Several recent investigations related to ceria-praseodymia mixed oxides can be found in the literature. These catalysts can be used for a large number of oxidation reactions. In fact, some of the authors of this manuscript have studied the catalytic activity of ceria-praseodymia mixed oxides for different applications, such as: VOC oxidation [46], CO oxidation [48], CO-PROX in comparison with $\mathrm{NO}$ oxidation to $\mathrm{NO}_{2}$ [49], CO-PROX reaction along with electrical conductivity measurements [50]. However, these catalysts are especially interesting for automotive exhaust aftertreatment technologies. In this sense, a few studies can be found recently in the literature on soot abatement, apart from some studies carried out in our group; such as the study of soot combustion in GDI context (without $\mathrm{NOx}$, and $\mathrm{O}_{2}$ only available in short pulses) [51] and a preliminary study where some selected $\mathrm{Ce}-\mathrm{Zr}$ mixed oxides were compared with some Ce-Pr ones (prepared by different synthesis routes) in terms of catalytic activity on soot oxidation, along with a commercial Pt-alumina catalyst [10]. Rico-Pérez et al. investigated the effect of copper incorporation to a ceria-praseodymia catalyst, maintaining a Ce/Pr ratio $\left(\mathrm{Ce}_{0.5} \operatorname{Pr}_{0.5} \mathrm{O}_{2-\delta}\right)$, towards $\mathrm{NO}$ oxidation to $\mathrm{NO}_{2}$ and soot oxidation [52], 
similarly to the investigation of Andana et al., who incorporated Pt nanoparticles [53]. Some other articles published studied the soot combustion process catalyzed by some ceria-praseodymia formulations [54, 55]. However, some considerations about these articles reported by Andana et al. [54] and Jeong et al. [55] should be mentioned: i) the corresponding authors did not study the NO oxidation to $\mathrm{NO}_{2}$ behaviors of these samples, which is of key importance to understand their catalytic activity towards soot combustion under NOx atmosphere; ii) they did not include a praseodymiumrich sample and a pure praseodymium oxide, in order to investigate the whole range of compositions, since their highest Pr atomic content is 0.5 ; iii) they used a soot/catalyst mass ratio of $1 / 9$ or $1 / 10$, respectively, which is not adjusted to realistic conditions, where soot/catalyst ratios are usually higher, since soot particles deposited onto a real catalytic device are in contact with a limited number of catalytically active sites; iv) they did not consider the effect of calcination temperature in order to study the effect of some high temperature peaks inside the catalytic device, since DPF can achieve $1000-1100^{\circ} \mathrm{C}$ due to the highly exothermal soot combustion reaction [23]. Considering these premises, the present investigation deals with the preparation and in-depth characterization of two series of $\mathrm{Ce}_{\mathrm{x}} \mathrm{Pr}_{1-\mathrm{x}} \mathrm{O}_{2-\delta}$ catalysts (with $\mathrm{x}=0,0.2,0.5,0.8$ and 1), thus ranging the whole $\mathrm{Ce} / \mathrm{Pr}$ ratios, calcined either at $500^{\circ} \mathrm{C}$ or $1000^{\circ} \mathrm{C}$, in order to check their catalytic activities after being exposed to high temperatures such as $1000^{\circ} \mathrm{C}$. Their catalytic performances were analyzed towards NO oxidation to $\mathrm{NO}_{2}$ and for soot combustion under different atmospheres, using a soot/catalyst mass ratio of $1 / 4$.

In summary, taking this into account, a detailed study of the composition effect on both the structural properties and the textural and surface properties in $\mathrm{Ce}_{\mathrm{x}} \mathrm{Pr}_{1-\mathrm{x}} \mathrm{O}_{2-\delta}(0<\mathrm{x}<1)$ mixed oxides will be carried out in this work, along with the pure cerium and praseodymium oxides. For this purpose, two calcination temperatures $\left(500^{\circ} \mathrm{C}\right.$ and $\left.1000^{\circ} \mathrm{C}\right)$ will be employed, in order to explore the effect of this parameter. The catalytic activity of these materials towards soot combustion will also be studied both under $\mathrm{NOx} / \mathrm{O}_{2}$ atmosphere and under $\mathrm{O}_{2} / \mathrm{N}_{2}$ atmosphere. Furthermore, the NO oxidation capacity to $\mathrm{NO}_{2}$ in the presence of $\mathrm{O}_{2}$ will be analyzed as well for the as-prepared catalysts. The catalytic activity of these ceria-praseodymia materials will be correlated with their textural and structural properties analyzed, in order to correlate trends in activity with the physicochemical characterization of the $\mathrm{Ce}_{\mathrm{x}} \mathrm{Pr}_{1-\mathrm{x}} \mathrm{O}_{2-\delta}(0<\mathrm{x}<1)$ samples.

\section{Experimental}




\subsection{Catalysts preparation}

Three compositions of $\mathrm{Ce}_{\mathrm{x}} \mathrm{Pr}_{1-\mathrm{x}} \mathrm{O}_{2-\delta}$ mixed oxides have been prepared with different nominal composition in cerium $(\mathrm{x}=0.8,0.5$ and 0.2$)$, together with the pure cerium and praseodymium oxides, respectively. These oxides have been synthesized by the co-precipitation method and calcined at both $500^{\circ} \mathrm{C}$ and $1000^{\circ} \mathrm{C}$. With the additional purpose of verifying the importance of the synthesis method, one of the compositions $\left(\mathrm{Ce}_{0.5} \mathrm{Pr}_{0.5} \mathrm{O}_{2-\delta}\right)$ has also been prepared by direct calcination of an intimate mixture of the precursor nitrates, and calcining this mixture at $500^{\circ} \mathrm{C}$ for 1 hour.

$\mathrm{Ce}_{\mathrm{x}} \operatorname{Pr}_{1-\mathrm{x}} \mathrm{O}_{2-\delta}$ mixed oxides were prepared by co-precipitation method in alkali media. For this purpose, the corresponding amounts of precursor salts were dissolved in distilled water: $\mathrm{Ce}\left(\mathrm{NO}_{3}\right)_{3} \cdot 6 \mathrm{H}_{2} \mathrm{O}$ (supplied by Aldrich, $99.99 \%$ of purity) and $\operatorname{Pr}\left(\mathrm{NO}_{3}\right)_{3} \cdot 6 \mathrm{H}_{2} \mathrm{O}$ (supplied by Aldrich, 99.9\% of purity). Once dissolved, the corresponding cerium and praseodymium hydroxides were coprecipitated by dropwise addition of an aqueous solution of ammonia until $\mathrm{pH} \approx 9$ is reached. The solid obtained was filtered and washed with distilled water. Afterwards, the samples were dried at $110^{\circ} \mathrm{C}$ during 12 hours in air. Finally, the solids were calcined in air with a heating ramp of $10^{\circ} \mathrm{C} / \mathrm{min}$ up to $500^{\circ} \mathrm{C}$ or $1000^{\circ} \mathrm{C}$. This maximum temperature was kept during 1 hour. On the other hand, pure ceria and pure praseodymia were obtained by precipitation, using the corresponding precursor salts, and following the same steps described for the mixed oxides.

The direct nitrate calcination method used to prepare a catalyst with $\mathrm{Ce}_{0.5} \operatorname{Pr}_{0.5} \mathrm{O}_{2-\delta}$ formulation was carried out by mixing the corresponding amounts of the above-mentioned precursor salts of Ce and Pr. These salts were tightly mixed in an agate mortar. After that, the mixture was calcined at $500^{\circ} \mathrm{C}$ during one hour in air (with a heating ramp of $10^{\circ} \mathrm{C} / \mathrm{min}$ ).

The nomenclature of the oxides synthesized by the co-precipitation method is $\mathrm{Ce}_{\mathrm{x}} \mathrm{Pr}_{1-\mathrm{x}} \mathrm{O}_{2-\delta}-\mathrm{T}$ (where $\mathrm{T}$ is referred to the temperature of calcination, $500^{\circ} \mathrm{C}$ or $1000^{\circ} \mathrm{C}$ ). This nomenclature is complemented with "-CAL" to indicate that the oxide was prepared by the nitrate calcination method $\left(\mathrm{Ce}_{0.5} \mathrm{Pr}_{0.5} \mathrm{O}_{2-\delta}-500-\mathrm{CAL}\right)$.

It is worth highlighting that the calcination treatment of the catalysts at $1000^{\circ} \mathrm{C}$ is used in this investigation in order to study the effect of a high temperature treatment on their catalytic activity. Thus, these samples can be considered as "thermally-aged", allowing the study of their behavior after possible high-temperature situations during the regeneration processes that might take place in a real DPF coated with the catalytic phase [23]. 


\subsection{Characterization techniques}

In order to determine the textural properties of the prepared $\mathrm{Ce}_{\mathrm{x}} \mathrm{Pr}_{1-\mathrm{x}} \mathrm{O}_{2-\delta}-\mathrm{T}$ oxides, the $\mathrm{N}_{2}$ physical adsorption technique at $-196^{\circ} \mathrm{C}$ has been performed. Regarding the determination of the structural properties, X-ray diffraction (XRD) and Raman spectroscopy techniques have been employed. In addition, X-ray photoelectron spectroscopy (XPS) has been used for the surface chemical characterization. Finally, temperature-programmed reduction tests with $\mathrm{H}_{2}\left(\mathrm{H}_{2}-\mathrm{TPR}\right)$ were used to explore the redox properties of the catalysts.

A detailed description of the parameters and conditions used in these techniques for the corresponding characterization of the samples was published elsewhere [56].

Briefly, $\mathrm{N}_{2}$ adsorption-desorption isotherms were carried out at $-196^{\circ} \mathrm{C}$ in an automatic volumetric device, after degassing the samples during 4 hours at $250^{\circ} \mathrm{C}$. X-ray diffractograms were collected using a Bruker D8 advance diffractometer between $10^{\circ}$ and $60^{\circ}(2 \theta)$, using a step size of $0.05^{\circ}$ and measuring each step during $3 \mathrm{~s}$. Raman spectra were obtained in a Bruker RFS 100/S Fourier Transform Raman Spectrometer with a power Nd:YAG laser source (1064 nm). It is worth noting that no significant heating of the samples was detected while collecting the Raman spectra.

With regard to XPS, a VG-Microtech Multilab electron spectrometer was employed, with a MgKa (1253.6 eV) radiation source. The binding and kinetic energies scales were adjusted by considering the $\mathrm{C} 1 s$ transition signal at $284.6 \mathrm{eV}$. Finally, the $\mathrm{H}_{2}-\mathrm{TPR}$ experiments were conducted after pre-treating the fresh samples in situ with a flow of $5 \% \mathrm{O}_{2} / \mathrm{He}$ and heating the samples up to $500^{\circ} \mathrm{C}\left(10^{\circ} \mathrm{C} / \mathrm{min}\right)$, keeping this temperature for 1 hour. The $\mathrm{H}_{2}$ reduction tests were performed after cooling down the samples, by using a flow of $35 \mathrm{ml} / \mathrm{min}$ in $5 \% \mathrm{H}_{2} / \mathrm{Ar}$. Experiments were carried out by heating the samples under this reductant atmosphere with a rate of $10^{\circ} \mathrm{C} / \mathrm{min}$ and reaching $1000^{\circ} \mathrm{C}$. $\mathrm{H}_{2}$-TPR analyses were conducted in a Micromeritics Pulse ChemiSorb 2705 device, which comprises a tubular quartz reactor coupled to a TCD detector.

Additional characterization techniques have been employed: $\mathrm{O}_{2}$ and $\mathrm{CO}_{2}$ temperature-programmed desorption experiments, and TEM images were also acquired. The corresponding description and results are presented in the Supplementary Material.

\subsection{Catalytic measurements}


Catalytic activity tests towards $\mathrm{NO}$ oxidation to $\mathrm{NO}_{2}$ and soot combustion reactions were carried out. The experimental device employed to perform these catalytic measurements were described in detail elsewhere [57].

Briefly, the catalytic tests were performed in a tubular quartz reactor coupled to specific NDIRUV gas analyzers (Fisher-Rosemount, models BINOS 100, 1004 and 1001) for specific $\mathrm{CO}, \mathrm{CO}_{2}$, $\mathrm{NO}, \mathrm{NO}_{2}$ and $\mathrm{O}_{2}$ monitoring. In all cases, the gas flow was kept in $500 \mathrm{ml} / \mathrm{min}\left(\mathrm{GHSV}=30,000 \mathrm{~h}^{-}\right.$ $\left.{ }^{1}\right)$. Both kinds of tests were performed with a heating ramp of $10^{\circ} \mathrm{C} / \mathrm{min}$ and reaching $700^{\circ} \mathrm{C}$.

On the one hand, the catalytic activity of these oxides towards soot combustion was studied using two different gas atmospheres: the first one composed of $500 \mathrm{ppm}$ of $\mathrm{NOx} / 5 \% \mathrm{O}_{2} / \mathrm{N}_{2}$ and the other one composed of $5 \% \mathrm{O}_{2} / \mathrm{N}_{2}$ (without NOx). The experimental set-up was made to ensure that the $\mathrm{NO}_{2}$ concentration fed to the reactor was negligible, since $\mathrm{NO}$ and $\mathrm{O}_{2}$ reactive gases come from different tanks and they are mixed close to the reactor inlet. In all the experiments, $80 \mathrm{mg}$ of catalyst were physically mixed with $20 \mathrm{mg}$ of soot under loose contact conditions (with spatula) and placed in the reactor along with $300 \mathrm{mg}$ of $\mathrm{SiC}$.

In order to better explore the catalytic activity of these samples towards soot combustion, some interesting parameters were calculated. Firstly, the T50\% $\left({ }^{\circ} \mathrm{C}\right)$ is the temperature when the $50 \%$ of soot conversion is achieved. And secondly, the real selectivity to $\mathrm{CO}(\%)$ is the relationship between the amount of $\mathrm{CO}$ emitted in the catalysed soot combustion and the total amount of $\mathrm{CO}$ and $\mathrm{CO}_{2}$ emitted in the soot combustion reaction without catalyst, by using Equation (1). Selectivity was calculated this way since ceria-based catalysts might be partially carbonated (with $\mathrm{CO}_{2}$ species), which could affect a reliable estimation of this parameter.

Real selectivity to $\mathrm{CO}(\%)=100 \cdot(\mathrm{mmol} \mathrm{CO})_{\text {with catalyst }} /\left(\mathrm{mmol} \mathrm{CO}+\mathrm{CO}_{2}\right)_{\text {without catalyst }}$

The repeatability of the catalysed soot combustion tests under loose contact conditions was checked and published elsewhere by our research group [10]. The same soot-catalyst mixture procedure described in this article was carried out in the present investigation. As it is described, according to reproducibility experiments, the error in the estimation of the T50\% temperature is \pm 2 ${ }^{\circ} \mathrm{C}[10]$.

On the other hand, the catalytic activity for the $\mathrm{NO}$ oxidation to $\mathrm{NO}_{2}$ in the presence of $\mathrm{O}_{2}$ (socalled "blank" experiments, without soot) was also studied, using the gas mixture composed of 500 ppm NOx $/ 5 \% \mathrm{O}_{2} / \mathrm{N}_{2} .80 \mathrm{mg}$ of catalyst were used in each experiment, along with $320 \mathrm{mg}$ of SiC. 


\section{Results and discussion}

\subsection{Characterization}

\subsubsection{Textural and structural characterization}

The crystalline structure of $\mathrm{Ce}_{\mathrm{x}} \mathrm{Pr}_{1-\mathrm{x}} \mathrm{O}_{2-\mathrm{x}} \mathrm{O}_{2-\delta}-\mathrm{T}$ oxides has been studied by X-ray diffraction, where "T" denotes the calcination temperature of the catalyst. The diffractograms of these oxides calcined at both $500^{\circ} \mathrm{C}$ (Figure 1a) and $1000^{\circ} \mathrm{C}$ (Figure 1b) are shown in Figure 1, together with the reference patterns for pure cerium and praseodymium oxides.

Pure cerium oxide calcined at $500^{\circ} \mathrm{C}$ presents typical reflections of a fluorite-type cubic structure, which is well described in the literature [29]. In the scanning range of 10 to $60^{\circ}$, the four typical reflections corresponding to the (111), (200), (220) and (311) planes are observed at 28.55, $33.05,47.5$ and $56.4^{\circ}$, respectively [58]. This diffractogram matches with the $\mathrm{CeO}_{2}$ standard reference diffractogram (JCPDS sheet 34-0394).

All the praseodymium-containing oxides that have been calcined at $500^{\circ} \mathrm{C}$ (Figure 1a), regardless of their composition, show a diffraction pattern with the four reflections corresponding to the above-mentioned cubic fluorite-type structure. However, these diffractograms are more complicated to analyze because praseodymium can form different oxides, both stoichiometric and nonstoichiometric, with $\mathrm{PrO}_{\delta}$ formula where $\mathrm{x} \leq 2[36,59]$. Because of this, the standard reference diffractograms of $\mathrm{PrO}_{2}, \mathrm{Pr}_{6} \mathrm{O}_{11}$ and $\mathrm{PrO}_{1.83}$ oxides (JCPDS sheets 24-1006, 42-1121 and 06-0329, respectively) have been included in Figure 1, which have a cubic structure with slightly different diffraction patterns than pure cerium oxide. Thus, for $\mathrm{Ce}_{\mathrm{x}} \mathrm{Pr}_{1-\mathrm{x}} \mathrm{O}_{2-\delta}$ oxides, and according to the bibliography [59-61], it is possible to obtain a solid solution for $0.3<\mathrm{x}<1$, since both the cerium oxide and the different praseodymium oxides crystallize in the same cubic fluorite-type structure. However, the diffractograms presented in Figure 1 relating to $\mathrm{Ce}_{\mathrm{x}} \mathrm{Pr}_{1-\mathrm{x}} \mathrm{O}_{2-\delta}-500$ show widened peaks and some asymmetry, and it cannot be ruled out phase segregation in these samples.

Taking into account the differences in the diffraction peaks position of the reference standard patterns shown in Figure 1, and comparing the position of the (111) peak of the pure $\mathrm{CeO}_{2}-500$ and $\mathrm{PrO}_{\delta}-500$ synthesized, a slight shift at lower values of $2 \theta$ is observed in the case of pure $\mathrm{PrO}_{2-\delta}-500$ 
with respect to pure $\mathrm{CeO}_{2}-500$. This fact indicates the existence of the non-stoichiometric oxides $\operatorname{Pr}_{6} \mathrm{O}_{11}$ and $\operatorname{PrO}_{1.83}$ in pure praseodymia calcined at $500^{\circ} \mathrm{C}$, together with the presence of stoichiometric $\mathrm{PrO}_{2}$. Another evidence that supports this aspect is the asymmetry of the diffraction peaks of this $\mathrm{PrO}_{2-\delta}-500$ oxide, being this asymmetry much more visible in the (220) and (311) peaks, which again suggests the existence of more than one praseodymium oxide phase in this sample.

Regarding the $\mathrm{Ce}_{0.5} \mathrm{Pr}_{0.5} \mathrm{O}_{2-\delta}$ composition calcined at $500^{\circ} \mathrm{C}$, which was prepared by both coprecipitation $\left(\mathrm{Ce}_{0.5} \mathrm{Pr}_{0.5} \mathrm{O}_{2-\delta}-500\right)$ and nitrate calcination $\left(\mathrm{Ce}_{0.5} \mathrm{Pr}_{0.5} \mathrm{O}_{2-\delta}-500-\mathrm{CAL}\right)$ methods, no significant differences were observed with respect to the (111) peak position. This maximum is $28.45^{\circ}$ for $\mathrm{Ce}_{0.5} \mathrm{Pr}_{0.5} \mathrm{O}_{2-\delta}-500$ and $28.5^{\circ}$ for $\mathrm{Ce}_{0.5} \mathrm{Pr}_{0.5} \mathrm{O}_{2-\delta}-500-\mathrm{CAL}$, which results in an identical experimental cell parameter for $\mathrm{Ce}_{0.5} \mathrm{Pr}_{0.5} \mathrm{O}_{2-\delta}-500-\mathrm{CAL}$ compared to its counterpart prepared by coprecipitation, as shown in Table 1 . However, there are differences in the intensity and width of the peaks in these diffractograms, an aspect related to the crystallinity of the oxides. Therefore, the diffraction peaks of the $\mathrm{Ce}_{0.5} \mathrm{Pr}_{0.5} \mathrm{O}_{2-8}-500-\mathrm{CAL}$ sample are more intense and slightly narrower than those of $\mathrm{Ce}_{0.5} \mathrm{Pr}_{0.5} \mathrm{O}_{2-\delta}-500$, indicating a higher crystallinity in the sample prepared by nitrate calcination.

The calcination treatment at $1000^{\circ} \mathrm{C}$ has allowed to demonstrate a clear phase segregation in the $\mathrm{Ce}_{0.2} \operatorname{Pr}_{0.8} \mathrm{O}_{2-\delta}$ composition, since the corresponding diffractogram of $\mathrm{Ce}_{0.2} \operatorname{Pr}_{0.8} \mathrm{O}_{2-\delta^{-}} 1000$ splits into two contributions in all the diffraction reflections. This splitting is also observed in a fifth peak corresponding to the (222) plane at $2 \theta$ values around $59^{\circ}$. This fifth peak is not observed in the diffractograms of samples calcined at $500^{\circ} \mathrm{C}$. Other authors such as Luo et al. [60] have also observed that for $\mathrm{Ce}_{\mathrm{x}} \mathrm{Pr}_{1-\mathrm{x}} \mathrm{O}_{2-\delta}$ oxides with $0.3<\mathrm{x}<0.7$, synthesized by the sol-gel method and calcined at $500^{\circ} \mathrm{C}$, only a part of the praseodymium cations forms a true solid solution with the cerium oxide, detecting also the coexistence of the $\mathrm{CeO}_{2}$ and $\operatorname{Pr}_{6} \mathrm{O}_{11}$ phases.

Further analysis of the most intense peak, (111), of the $\mathrm{Ce}_{0.2} \mathrm{Pr}_{0.8} \mathrm{O}_{2-\delta}$ diffractogram (Figure 1b) shows a contribution with a first maximum at $2 \theta$ position of $28.25^{\circ}$, and a maximum of the second contribution at $28.6^{\circ}$. The position of the peak contribution at lower $2 \theta$ values $\left(28.25^{\circ}\right)$ coincides exactly with the maximum of the (111) peak of pure $\mathrm{PrO}_{2-\delta}-1000$. It is also equal to the second contribution at higher $2 \theta$ values $\left(28.6^{\circ}\right)$ with the maximum (111) peaks of the other two $\mathrm{Ce}_{0.8} \operatorname{Pr}_{0.2} \mathrm{O}_{2 \text { - }}$ ${ }_{\delta}-1000$ and $\mathrm{Ce}_{0.5} \operatorname{Pr}_{0.5} \mathrm{O}_{2-\delta}-1000$ compositions, so it can be deduced that there will be a segregated phase similar to praseodymia and another segregated phase that seems to contain a higher cerium content than the nominal composition. 
On the contrary, the calcination at $1000^{\circ} \mathrm{C}$ of the $\mathrm{Ce}_{0.8} \mathrm{Pr}_{0.2} \mathrm{O}_{2-\delta}$ and $\mathrm{Ce}_{0.5} \mathrm{Pr}_{0.5} \mathrm{O}_{2-\delta}$ compositions confirms the existence of a single cubic phase, with no phase segregation observed in these cases, which proves the existence of crystalline stability in the $\mathrm{Ce}_{\mathrm{x}} \mathrm{Pr}_{1-\mathrm{x}} \mathrm{O}_{2-\delta}$ oxides prepared with $0.5<\mathrm{x}<$ 1.

When pure $\mathrm{PrO}_{2-\delta}$ oxide is calcined at $1000^{\circ} \mathrm{C}$, the diffraction peaks lose the asymmetry they showed after calcination at $500^{\circ} \mathrm{C}$. Furthermore, after calcination at $1000^{\circ} \mathrm{C}$, the contribution of $\mathrm{PrO}_{2}$ stoichiometric oxide is negligible, as the $\mathrm{PrO}_{2-\delta^{-}}-1000$ diffraction peaks are almost perfectly matched to the $\operatorname{Pr}_{6} \mathrm{O}_{11}$ and $\mathrm{PrO}_{1.83}$ diffraction peaks (files JCPDS 42-1121 and 06-0329, respectively), and therefore this non-stoichiometric structures (which are indistinguishable by XRD) are predominant in pure $\mathrm{PrO}_{2-\delta}-1000$ oxide. In addition, the population of $\mathrm{Pr}^{3+}$ cations in $\mathrm{PrO}_{2-\delta}$ is higher when calcined at $1000^{\circ} \mathrm{C}$ than when calcined at $500^{\circ} \mathrm{C}$. In fact, the high stability of the non-stoichiometric $\mathrm{PrO}_{2-\delta}$ at high temperatures and under oxidizing atmosphere is described in the literature, in contrast with the low non-stoichiometry characteristic of ceria [38].

Table 1 shows the values of the experimental cubic cell parameter $(a)$, calculated from the diffractograms, along with the BET surface area values of the $\mathrm{Ce}_{\mathrm{x}} \operatorname{Pr}_{1-\mathrm{x}} \mathrm{O}_{2-\delta}$ oxides calcined at both $500^{\circ}$ and $1000^{\circ} \mathrm{C}$. A complete Table with the whole BET surface areas (obtained as average of three measurements for every catalyst) is shown in the Supplementary Information (Table S1).

It is important to clarify that, due to the aforementioned widening of the diffraction peaks of $\mathrm{Ce}_{\mathrm{x}} \mathrm{Pr}_{1-\mathrm{x}} \mathrm{O}_{2-\delta}$ oxides calcined at $500^{\circ} \mathrm{C}$, and due to the fact that a refining technique was not used to calculate the cubic cell parameter of these materials, the cell parameter values shown in Table 1 are not entirely real, but they should be considered as "apparent cubic cell parameters".

The cell parameter values of $\mathrm{Ce}_{0.2} \mathrm{Pr}_{0.8} \mathrm{O}_{2-\delta}-500, \mathrm{PrO}_{2-\delta}-500$ and $\mathrm{Ce}_{0.2} \mathrm{Pr}_{0.8} \mathrm{O}_{2-\delta}-1000$ have not been included in Table 1 because, on the one hand, the two previous oxides calcined at $500^{\circ} \mathrm{C}$ present a diffraction (111) peak with a rather accentuated asymmetry, as a consequence of the possible presence of more than one phase. On the other hand, in $\mathrm{Ce}_{0.2} \mathrm{Pr}_{0.8} \mathrm{O}_{2-\delta}-1000$ the diffraction (111) peak is completely split due to the presence of segregated phases. Therefore, it has been considered more appropriate not to present any apparent cell parameter value for these three cases.

The doping of pure $\mathrm{CeO}_{2}-500$ oxide with 20 at $\%$ in praseodymium leads to a slight increase in the BET area (from 54 to $67 \mathrm{~m}^{2} / \mathrm{g}$ ). This trend in the BET surface area was also observed by other authors. In this sense, Reddy et al. [34] obtained a $\mathrm{Ce}_{0.8} \operatorname{Pr}_{0.2} \mathrm{O}_{2-\delta}$ mixed oxide through very similar synthesis conditions than those used in this work (co-precipitation and calcination at $500^{\circ} \mathrm{C}$, but using 
5 hours of calcination instead of 1 hour), with a BET surface area of $72 \mathrm{~m}^{2} / \mathrm{g}$, being this area larger than that of pure ceria prepared under the same conditions $\left(41 \mathrm{~m}^{2} / \mathrm{g}\right.$ for pure ceria). This same BET area of $72 \mathrm{~m}^{2} / \mathrm{g}$ was observed in a mixed oxide of $\mathrm{Ce}_{0.81} \operatorname{Pr}_{0.19} \mathrm{O}_{2-\delta}$ supplied by the company Grace [62]. However, the synthesized $\mathrm{Ce}_{\mathrm{X}} \mathrm{Pr}_{1-\mathrm{x}} \mathrm{O}_{2-\delta}-500$ oxides with an atomic praseodymium content between $50 \%$ and $100 \%$ have a significantly lower BET area than pure $\mathrm{CeO}_{2}-500$, in the range of 37 to $18 \mathrm{~m}^{2} / \mathrm{g}$. This same situation was observed by Rajendran et al. [59], who synthesized a $\mathrm{Ce}_{0.3} \operatorname{Pr}_{0.7} \mathrm{O}_{2 \text { - }}$ $\delta$ oxide, by a combustion method in solution, with urea at $500^{\circ} \mathrm{C}$; after this process, a BET area of only $22 \mathrm{~m}^{2} / \mathrm{g}$ was obtained. Thus, this oxide lost specific surface area with respect to pure ceria prepared by the same synthesis route $\left(79 \mathrm{~m}^{2} / \mathrm{g}\right)$.

Calcination at $1000^{\circ} \mathrm{C}$ clearly leads to a decrease in the BET surface area of these oxides, with values in the range of 1 to $4 \mathrm{~m}^{2} / \mathrm{g}$. Rajendran et al. [59] also observed a significant decrease in the BET surface area of $\mathrm{Ce}_{\mathrm{x}} \mathrm{Pr}_{1-\mathrm{x}} \mathrm{O}_{2-\delta}$ oxides when using a calcination temperature higher than $500^{\circ} \mathrm{C}$ $\left(850^{\circ} \mathrm{C}\right.$ in this case, obtaining BET area values between 0.9 and $\left.3.6 \mathrm{~m}^{2} / \mathrm{g}\right)$, which are very consistent with the results of this work. However, the $\mathrm{Ce}_{x} \operatorname{Pr}_{1-\mathrm{x}} \mathrm{O}_{2-\delta}$ mixed oxides calcined at $1000^{\circ} \mathrm{C}$ have a slightly higher BET area value than that obtained for pure $\mathrm{CeO}_{2}-1000$ oxide (Table 1), which suggests that the insertion of praseodymium into the ceria network makes the accentuated thermal sintering shown in $\mathrm{CeO}_{2}-1000$ difficult, somehow.

With regard to the apparent cubic cell parameter values of the oxides calcined at $500^{\circ} \mathrm{C}$, calculated from the diffractograms, it is observed that the insertion of praseodymium into the ceria network causes an increase in the unit cell parameter. This aspect, which has been observed by several authors [34-38, 59], finds its justification in the values of the ionic radii of the cations involved in the oxide. These values are collected in Table 2.

Although the $\mathrm{Ce}^{4+}$ cation radius is very similar to that of $\operatorname{Pr}^{4+}(0.097 \mathrm{~nm}$ and $0.096 \mathrm{~nm}$, respectively), in $\mathrm{Ce}_{x} \operatorname{Pr}_{1-\mathrm{x}} \mathrm{O}_{2-\delta}$ oxides, part of the praseodymium can be found as $\operatorname{Pr}^{3+}[36,64]$ being the size of $\operatorname{Pr}^{3+}(0.1126 \mathrm{~nm})$ greater than that of $\mathrm{Pr}^{4+}$ and $\mathrm{Ce}^{4+}$. Therefore, the apparent cubic cell parameter of pure $\mathrm{CeO}_{2}-500$ is increased from 0.5415 to $0.5424 \mathrm{~nm}$ when doping with 20 at\% in praseodymium. For the $\mathrm{Ce}_{0.5} \operatorname{Pr}_{0.5} \mathrm{O}_{2-\delta}$ composition calcined at $500^{\circ} \mathrm{C}$, two different values have been obtained for the apparent cubic cell parameter, depending on the preparation method used. Thus, when the co-precipitation method is employed, the cell parameter obtained is $0.5433 \mathrm{~nm}$, greater than the cell parameter of the $\mathrm{Ce}_{0.8} \mathrm{Pr}_{0.2} \mathrm{O}_{2-\delta}-500$, as expected. However, when using the nitrate calcination method $\left(\mathrm{Ce}_{0.5} \mathrm{Pr}_{0.5} \mathrm{O}_{2-\delta}-500-\mathrm{CAL}\right)$, the cell parameter obtained $(0.5424 \mathrm{~nm})$ is slightly smaller than that of the counterpart oxide prepared by co-precipitation. This difference could be devoted to a lower 
percentage of praseodymium insertion into the ceria network when using the nitrate calcination method, leading to an apparent cell parameter identical to that of $\mathrm{Ce}_{0.8} \operatorname{Pr}_{0.2} \mathrm{O}_{2-\delta}-500$.

All the results presented above are broadly in line with those obtained by other authors $[59,65]$. Thus, Borchert et al. [36] have also observed a gradual increase in the cell parameter from pure $\mathrm{CeO}_{2}$ oxide to the intermediate composition $\mathrm{Ce}_{0.5} \mathrm{Pr}_{0.5} \mathrm{O}_{2-\delta}$, synthesizing these oxides using the Pechini method, based on the use of a polymeric complex, and using a calcination temperature of $500^{\circ} \mathrm{C}$, which shows that, for $\mathrm{Ce}_{\mathrm{x}} \operatorname{Pr}_{1-\mathrm{x}} \mathrm{O}_{2-\delta}$ compositions (with $0.5<\mathrm{x}<1$ ), praseodymium can be progressively incorporated into the ceria network.

A very appropriate way to verify the degree of the solid solution formation is to use Vegard's law, which assumes that changes in the parameters of the unit cell with the composition are governed by the relative sizes of the atoms or ions that are active in the mechanism of solid dissolution [66]. According to this law, Rajendran et al. [59] have estimated some expressions for the theoretical calculation of the cubic cell parameter of the $\mathrm{Ce}_{\mathrm{x}} \mathrm{Pr}_{1-\mathrm{x}} \mathrm{O}_{2-\delta}$ system based on the praseodymium content. On the one hand, the following expression corresponds to a linear relationship between the cell parameter $(a$, in $\mathrm{nm})$ and the atomic content in praseodymium $(x$, in percentage). For a solid solution between $\mathrm{CeO}_{2}$ and $\mathrm{PrO}_{2}$ oxides, where both cations are in a tetravalent oxidation state, the expression has been obtained from the theoretical cell parameters of JCPDS 34-0394 and 24-1006 $\left(a_{\mathrm{CeO} 2}=\right.$ $0.5411 \mathrm{~nm}$ and $\left.a_{P r O 2}=0.5391 \mathrm{~nm}\right)$, respectively.

$$
a(\mathrm{~nm})=-0.00002 \cdot x+0.5411
$$

Since the $\operatorname{Pr}^{4+} / \operatorname{Pr}^{3+}$ pair has a higher reduction potential than the $\mathrm{Ce}^{4+} / \mathrm{Ce}^{3+}$ pair [41], the $\mathrm{Ce}_{x} \operatorname{Pr}_{1-}$ ${ }_{\mathrm{x}} \mathrm{O}_{2-\delta}$ system has a considerably higher oxygen release efficiency from the lattice $[35,38,64]$ regarding pure ceria, due to the reduction of tetravalent cations (mostly $\mathrm{Pr}^{4+}$ ) to the trivalent state. For this reason, a second expression is presented for the theoretical calculation of the cell parameter as a function of the praseodymium content for a solid solution between the $\mathrm{CeO}_{2}$ and $\mathrm{Pr}_{6} \mathrm{O}_{11}$ oxides, using in this case the JCPDS 34-0394 and 42-1121 files ( $a_{\mathrm{CeO} 2}=0.5411 \mathrm{~nm}$ and $\left.a_{\mathrm{Pr} 6011}=0.5470 \mathrm{~nm}\right)$, respectively.

$$
a(\mathrm{~nm})=0.00006 \cdot x+0.5411
$$

These two linear relationships have been represented in Figure 2, together with the experimental values of apparent cubic cell parameter for the $\mathrm{Ce}_{\mathrm{x}} \operatorname{Pr}_{1-\mathrm{x}} \mathrm{O}_{2-\delta}-500$ and $\mathrm{Ce}_{\mathrm{x}} \operatorname{Pr}_{1-\mathrm{x}} \mathrm{O}_{2-\delta}-1000$ mixed oxides, obtained by XRD. 
Figure 2 is an attempt to represent the insertion of a certain amount of praseodymium into the structure of ceria for $\mathrm{Ce}_{\mathrm{x}} \mathrm{Pr}_{1-\mathrm{x}} \mathrm{O}_{2-\delta}-500$ mixed oxides with $\mathrm{x}=0.8$ and 0.5 , thus confirming that part of the inserted praseodymium is in a trivalent state. However, $\mathrm{Ce}_{0.8} \operatorname{Pr}_{0.2} \mathrm{O}_{2-\delta}-500$ presents a considerable praseodymium insertion due to the good correlation between the experimental value of apparent cell parameter and the calculated one, using equation (3). This was observed by other authors such as Shuk et al. [65], who obtained a cell parameter for the $\mathrm{Ce}_{0.8} \operatorname{Pr}_{0.2} \mathrm{O}_{2-\delta}$ composition $(0.5422 \mathrm{~nm})$ very similar to that obtained in this study for this same composition. Meanwhile, in $\mathrm{Ce}_{0.5} \mathrm{Pr}_{0.5} \mathrm{O}_{2-\delta^{-}} 500$ composition, a part of the praseodymium does not seem to be inserted into the ceria structure, obtaining an even worse praseodymium insertion if this composition is prepared by the nitrate calcination method. Therefore, the presence of crystalline domains and/or nano-domains of different $\mathrm{Ce} / \mathrm{Pr}$ compositions coexisting in the same catalysts (indistinguishable by XRD) cannot be excluded for this set of samples. This can be an indirect explanation about the reasons why the BET surface areas do not follow a regular or gradual trend with the increase of Pr loading. Complementary characterization results, consisting of $\mathrm{O}_{2}$-TPD tests, compiled on the Supplementary Information, illustrate the $\mathrm{O}_{2}$ evolution for this set of catalysts under inert atmosphere, with complex and multimodal profiles of $\mathrm{O}_{2}$ emission, without obeying regular patterns with $\mathrm{Pr}$ contents, mainly observed for rich-Pr content samples. This can also support the existence of heterogeneous domains on samples.

On the other hand, if the samples calcined at $1000^{\circ} \mathrm{C}$ are considered (Figure 2, red squares), the cell parameter decreases for those containing $\mathrm{x}=0.8$ and 0.5 . The same observation was collected by Borchert et al. [36] in similar oxides calcined at $1400^{\circ} \mathrm{C}$. This seems to be because calcination at $1000^{\circ} \mathrm{C}$ leads to a higher oxidation degree of the $\mathrm{Ce}_{0.8} \operatorname{Pr}_{0.2} \mathrm{O}_{2-\delta}$ and $\mathrm{Ce}_{0.5} \operatorname{Pr}_{0.5} \mathrm{O}_{2-\delta}$ oxides, with tetravalent oxidation states predominating for both cerium and praseodymium, presenting lower atomic radii than for trivalent oxidation states (Table 2). Other authors such as Takasu et al. [67] also observed a slight decrease in the cell parameter with $0.2<\mathrm{x}<1$ in the $\mathrm{Ce}_{\mathrm{x}} \operatorname{Pr}_{1-\mathrm{x}} \mathrm{O}_{2-\delta}$, when using a calcination temperature of $1400^{\circ} \mathrm{C}$. Regarding these observations, Sovestnov et al. [68] indicated that the cell parameter values for the $\mathrm{Ce}_{\mathrm{x}} \mathrm{Pr}_{1-\mathrm{x}} \mathrm{O}_{2-\delta}$ mixed oxides with $0<\mathrm{x}<1$, as well as the formal oxidation state of praseodymium, strongly depend on samples preparation and treatments. Thus, higher cell parameters than pure ceria for $\mathrm{Ce}_{\mathrm{x}} \operatorname{Pr}_{1-\mathrm{x}} \mathrm{O}_{2-\delta}$ with $0<\mathrm{x}<1$ are consistent with a moderate calcination temperature $\left(500^{\circ} \mathrm{C}\right)$ and an appreciable concentration of $\mathrm{Pr}^{3+}$, while cell parameter values lower than pure ceria are consistent with a higher calcination temperature $\left(1000^{\circ} \mathrm{C}\right)$. All these aspects reveal that the synthesis conditions influence the prevalence of one oxidation state or another for praseodymium and thus the value of the cell parameter [59]. 
On the other hand, an opposite trend can be stated for pure praseodymia, i.e. calcination at $1000^{\circ} \mathrm{C}$ increases the presence of oxygen vacancies, which is indicative of an abundant presence of $\mathrm{Pr}^{3+}$, resulting in a cell parameter compatible with $\mathrm{Pr}_{6} \mathrm{O}_{11}$ and/or $\mathrm{PrO}_{1.83}$ stoichiometry.

Raman spectroscopy is a very appropriate technique for the structural characterization of cerium-based oxides. This technique provides structural information complementary to that offered by the XRD technique. XRD technique provides information mainly related to the position of large cations in the crystalline lattice (such as cerium), but this technique offers very low sensitivity to light elements (such as oxygen) [69]. Raman spectroscopy provides information about the anion lattice, for which the XRD technique is not very sensitive. In this sense, it reveals the presence of defects in this framework and the arrangement of the M-O bonds.

Figure 3 shows the Raman spectra of $\mathrm{Ce}_{\mathrm{x}} \operatorname{Pr}_{1-\mathrm{x}} \mathrm{O}_{2-\delta}$ oxides calcined at $500^{\circ} \mathrm{C}$ and $1000^{\circ} \mathrm{C}$. It is observed that for pure ceria, either calcined at $500^{\circ} \mathrm{C}$ or $1000^{\circ} \mathrm{C}$, its Raman spectrum is characterized by a narrow and very intense band around $464 \mathrm{~cm}^{-1}$. This defined band is attributed to the vibration mode of the active $\mathrm{Ce}-\mathrm{O}$ bond in Raman $\left(\mathrm{F}_{2 g}\right.$ mode) of the fluorite-type cubic structure in which this oxide crystallizes, corresponding to a symmetrical vibration mode of the oxygen atoms surrounding the cerium cations [70]. Since only the $\mathrm{O}^{2-}$ anions move in this symmetrical vibration mode, the frequency is therefore virtually independent on the cation mass [71].

With respect to pure praseodymia, either calcined at $500^{\circ} \mathrm{C}$ or $1000^{\circ} \mathrm{C}$, its Raman spectrum could not be obtained as a result of the high fluorescence of this oxide during the analysis. Other authors $[37,60]$ have also detected the presence of the fluorescence effect in oxides with high praseodymium content, making it impossible to obtain their Raman spectra.

The Raman band associated with the $\mathrm{F}_{2 \mathrm{~g}}$ vibration mode is present in the spectra of $\mathrm{Ce}_{\mathrm{x}} \mathrm{Pr}_{1-\mathrm{x}} \mathrm{O}_{2-}$ ${ }_{\delta}$ oxides calcined at $500^{\circ} \mathrm{C}$ and $1000^{\circ} \mathrm{C}$, which confirms that these mixed oxides also crystallize in a cubic fluorite-type structure. However, three effects can be observed in this $F_{2 g}$ band as the amount of praseodymium increases in the oxide:

(i) A sharp decrease in this band intensity, as well as of the entire Raman spectrum.

(ii) A progressive widening of the $\mathrm{F}_{2 \mathrm{~g}}$ band, with a progressive asymmetry in the tail at lower wavelengths of this band.

(iii) A clear shift of this $F_{2 g}$ band to lower wavenumbers (more important for samples calcined at $\left.500^{\circ} \mathrm{C}\right)$. 
With regard to the effect of the intensity loss of the Raman spectra as the praseodymium content increases, this should be carefully analyzed, although the praseodymium element produces fluorescence, masking the Raman bands as indicated above, a part of the attenuation in the intensity of the $F_{2 g}$ band is also due to the effect of the symmetry loss itself in the ceria lattice when introducing the praseodymium dopant. It affects the oxygen vibration with regard to its equilibrium position. In addition, the $\mathrm{F}_{2 \mathrm{~g}}$ band widening is also derived from this distortion in the anion framework symmetry of ceria by introducing the praseodymium dopant, as the $\mathrm{Pr}^{4+}$ cation is more easily reduced to $\mathrm{Pr}^{3+}$ than the $\mathrm{Ce}^{4+}$ cation to $\mathrm{Ce}^{3+}$, with the $\mathrm{Pr}^{3+}$ cation being larger than $\mathrm{Pr}^{4+}$ and $\mathrm{Ce}^{4+}$ cations (Table 2). Accordingly, it is expected that the presence of these $\operatorname{Pr}^{3+}$ cations will also promote the $\mathrm{F}_{2 \mathrm{~g}}$ band shift towards lower wavenumbers as the praseodymium content increases, as a consequence of an increase in the M-O bond distances. It would be in good agreement with the apparent cell parameter values calculated from the diffractograms of these mixed oxides (Table 1). Thus, the following Figure 4 shows the relationship between the position of the maximum $\mathrm{F}_{2 \mathrm{~g}}$ band and the atomic $\operatorname{Pr} \%$ content in $\mathrm{Ce}_{\mathrm{x}} \mathrm{Pr}_{1-\mathrm{x}} \mathrm{O}_{2-\delta}$ oxides calcined at $500^{\circ} \mathrm{C}$ and $1000^{\circ} \mathrm{C}$.

Figure 4 confirms the introduction of praseodymium cations into the fluorite lattice of ceria, revealing an increasing incorporation of praseodymium in this framework by enhancing the praseodymium content. However, despite the linear relationship presented in Figure 4, partial segregation of praseodymium oxides cannot be excluded, as will be indicated by the surface analysis of these oxides by XPS (presented below).

On the other hand, Figure 4 also shows that for the same nominal composition of cerium and praseodymium in the mixed oxide, the maximum of the $F_{2 g}$ band is less shifted towards lower wavenumbers when it is calcined at $1000^{\circ} \mathrm{C}$. This observation appears to be due to the lower population of both $\mathrm{Pr}^{3+}$ and $\mathrm{Ce}^{3+}$ in the lattice when subjected to a temperature of $1000^{\circ} \mathrm{C}$, which leads to a shorter $\mathrm{M}-\mathrm{O}$ bond, thus requiring more energy (reflected in higher wavenumbers) to vibrate. This fact is fully in accordance with the conclusions reached after the analysis of the apparent cubic cell parameters of $\mathrm{Ce}_{x} \mathrm{Pr}_{1-\mathrm{x}} \mathrm{O}_{2-\delta}$ oxides calcined at both $500^{\circ} \mathrm{C}$ and $1000^{\circ} \mathrm{C}$ (Figure 2), where a significant decrease in the cell parameter of the $\mathrm{Ce}_{\mathrm{x}} \mathrm{Pr}_{1-\mathrm{x}} \mathrm{O}_{2-\delta}$ oxides was observed with $\mathrm{x}=0.8$ and 0.5 after calcination at $1000^{\circ} \mathrm{C}$ for the lowest population of $\mathrm{Pr}^{3+}$ and $\mathrm{Ce}^{3+}$ cations. On the other hand, it cannot be ruled out that calcination at $1000^{\circ} \mathrm{C}$ could induce a greater segregation of praseodymium, which would also contribute to a lower shift of the $\mathrm{F}_{2 \mathrm{~g}}$ band with respect to that observed in this band for the same composition calcined at $500^{\circ} \mathrm{C}$.

With respect to the $\mathrm{Ce}_{0.5} \mathrm{Pr}_{0.5} \mathrm{O}_{2-8}-500-\mathrm{CAL}$ mixed oxide prepared by direct calcination of nitrates, the maximum $\mathrm{F}_{2 \mathrm{~g}}$ band of its Raman spectrum is positioned at slightly higher wavenumbers 
than the maximum of this band in the homologous oxide prepared by co-precipitation $\left(\mathrm{Ce}_{0.5} \operatorname{Pr}_{0.5} \mathrm{O}_{2-}\right.$ ${ }_{\delta}$-500). This finding was to be expected since a smaller apparent cell parameter was previously observed by XRD in $\mathrm{Ce}_{0.5} \mathrm{Pr}_{0.5} \mathrm{O}_{2-\delta}-500-\mathrm{CAL}$ oxide. Both observations indicate a lower insertion of the praseodymium cation in the ceria structure when using the nitrate calcination method instead of the co-precipitation method.

Another aspect that confirms the insertion of part of the praseodymium in the fluorite structure of ceria is the appearance of a weak band, around $570 \mathrm{~cm}^{-1}$, in the Raman spectra of the $\mathrm{Ce}_{\mathrm{x}} \operatorname{Pr}_{1-\mathrm{x}} \mathrm{O}_{2-}$ ${ }_{\delta}$. According to the literature $[19,34,37,60,70]$, this band is attributed to the presence of oxygen vacancies in the oxide structure, leading to loss of symmetry in the anion lattice of the oxide [70]. When $\mathrm{Ce}^{4+}$ cations are replaced by $\mathrm{Pr}^{3+}$ or $\mathrm{Ce}^{3+}$ cations, oxygen vacancies are created in order to maintain neutrality in the oxide charge balance. It is well known that these oxygen vacancies improve the diffusion rate of the $\mathrm{O}^{2-}$ anion in the oxide, thus increasing the ease with which the material is able to uptake and release oxygen under oxidizing and reducing conditions respectively [37, 70$]$. This weak band, absent in pure ceria calcined at $500^{\circ} \mathrm{C}$ and $1000^{\circ} \mathrm{C}$, is noticeable in $\mathrm{Ce}_{0.8} \operatorname{Pr}_{0.2} \mathrm{O}_{2-\delta}$ and $\mathrm{Ce}_{0.5} \mathrm{Pr}_{0.5} \mathrm{O}_{2-\delta}$ compositions calcined at both $500^{\circ} \mathrm{C}$ and $1000^{\circ} \mathrm{C}$. However, this band is not clearly defined in the $\mathrm{Ce}_{0.2} \mathrm{Pr}_{0.8} \mathrm{O}_{2-\delta}$ composition. One of the reasons of this fact is the significant loss of the Raman signal in this spectrum due to the fluorescence effect. However, the shift towards lower wavenumbers of the maximum $\mathrm{F}_{2 \mathrm{~g}}$ band confirmed the insertion of some praseodymium into the ceria structure.

\subsubsection{Surface characterization by XPS}

A further description of this technique can be found in the Supplementary Material. The results of XPS are shown in Table 3, in which the surface concentrations of $\mathrm{Ce}, \mathrm{Pr}, \mathrm{O}$ and $\mathrm{C}$ are presented in atomic percentages as well as the $\mathrm{Ce} / \mathrm{Pr}$ surface atomic ratio, the proportion of $\mathrm{Ce}^{3+}$ to the total amount of cerium in surface and the proportion of $\operatorname{Pr}^{3+}$ to the total amount of praseodymium in surface for the synthesized oxides.

The Ce/Pr ratio shown in Table 3 is always lower than the nominal value (value in parentheses), which reveals significant praseodymium enrichment on the particle surface. The segregation of the doping cations on the surface and boundaries in cerium oxides is a well-known phenomenon [72]. In the case of praseodymium-doped nanocrystalline cerium oxide, segregation of $\operatorname{Pr}^{3+}$ and $\operatorname{Pr}^{4+}$ cations in the boundaries can create pathways for rapid oxygen diffusion under chemical control [73]. Thus, 
Borchert et al. [36] studied in detail the segregation of the praseodymium dopant in the ceria framework using SIMS and XPS techniques. These authors revealed the segregation of praseodymium cations on the surface for all samples, as found in all $\mathrm{Ce}_{\mathrm{x}} \mathrm{Pr}_{1-\mathrm{x}} \mathrm{O}_{2-\delta}-\mathrm{T}$ oxides synthesized in this study; further indicating that praseodymium segregation occurs not only on the surface but also in a large number of grain boundaries of the oxide nanostructure. On the other hand, the systematic increase observed in Figure 2 of the apparent cubic cell parameter by increasing the molar $\operatorname{Pr} \%$ in $\mathrm{Ce}_{\mathrm{x}} \operatorname{Pr}_{1-\mathrm{x}} \mathrm{O}_{2-\delta}-500$ oxides with $0.5<\mathrm{x}<1$ also seems to suggest that an important part of praseodymium is incorporated into the ceria lattice $[36,38,59]$.

The surface enrichment in praseodymium has also been observed by other authors in commercial samples supplied by the company Grace [62], showing the mixed oxide with $\mathrm{Ce}_{0.81} \operatorname{Pr}_{0.19} \mathrm{O}_{2-\delta}$ composition a surface enrichment factor in praseodymium of 2.42 . This factor was calculated as the ratio between the nominal Ce/Pr ratio and the surface Ce/Pr ratio obtained by XPS. The $\mathrm{Ce}_{0.8} \operatorname{Pr}_{0.2} \mathrm{O}_{2-\delta}-500$ oxide prepared in this study by co-precipitation presents a surface enrichment factor in praseodymium very similar (2.50) to the commercial sample supplied by the company Grace. These results clearly indicate that the enrichment degree in praseodymium is not attributable to the preparation method, as commercial samples and those prepared by different processes and calcined at different temperatures show some surface enrichment in praseodymium.

In the study of Ozawa et al. [74] the chemical causes of this surface praseodymium enrichment of $\mathrm{Ce}_{\mathrm{x}} \mathrm{Pr}_{1-\mathrm{x}} \mathrm{O}_{2-\delta}$ oxides are reported. These authors confirm that after dissolving the precursor cerium and praseodymium nitrate salts, the precipitation in alkaline medium and the drying at $110^{\circ} \mathrm{C}$ of this precipitate, the fluorite phase corresponding to cerium oxide $\left(\mathrm{CeO}_{2}\right)$ is detected, while praseodymium forms a hexagonal trihydroxide, with $\operatorname{Pr}(\mathrm{OH})_{3}$ stoichiometry. In this way, $\mathrm{CeO}_{2}$ species maintain their cubic structure during the calcination process, with a slight weight loss around $100-150^{\circ} \mathrm{C}$ due to the loss of adsorbed water in the fine $\mathrm{CeO}_{2}$ particles. However, the $\operatorname{Pr}(\mathrm{OH})_{3}$ species undergoes a first decomposition to $\mathrm{PrOOH}$ species around $400^{\circ} \mathrm{C}$, forming the $\mathrm{PrO}_{2-\delta}$ oxide at temperatures above $400^{\circ} \mathrm{C}$. Thus, the formation of different chemical species of cerium and praseodymium after the precipitation and drying stages lead to the existence of different decomposition kinetics during the last calcination stage at $500^{\circ} \mathrm{C}$, which finally prevents a completely homogeneous distribution of both cations in the particles; thus yielding praseodymium surface enrichment of the $\mathrm{Ce}_{\mathrm{x}} \operatorname{Pr}_{1-\mathrm{x}} \mathrm{O}_{2-\delta}$ compositions with $\mathrm{x}=0.8,0.5$ and 0.2 .

The calcination at $1000^{\circ} \mathrm{C}$ of these three $\mathrm{Ce}_{\mathrm{x}} \mathrm{Pr}_{1-\mathrm{x}} \mathrm{O}_{2-\delta}$ compositions with $\mathrm{x}=0.8,0.5$ and 0.2 has allowed us to observe an increase in the surface enrichment of praseodymium when these mixed oxides are subjected to this heating treatment, which results in a lower $\mathrm{Ce} / \mathrm{Pr}$ surface atomic ratio 
(Table 3). Thus, for $\mathrm{Ce}_{0.8} \mathrm{Pr}_{0.2} \mathrm{O}_{2-\delta^{-}} 1000$ and $\mathrm{Ce}_{0.5} \mathrm{Pr}_{0.5} \mathrm{O}_{2-\delta^{-}} 1000$, this $\mathrm{Ce} / \mathrm{Pr}$ atomic ratio decreases by $25 \%$ and $20 \%$ respectively with respect to the atomic ratio of the same oxide but calcined at $500^{\circ} \mathrm{C}$. On the other hand, the Ce/Pr atomic ratio of the mixed oxide containing the highest praseodymium content, $\mathrm{Ce}_{0.2} \operatorname{Pr}_{0.8} \mathrm{O}_{2-\delta}$, suffers a $36 \%$ decrease when the oxide is calcined at $1000^{\circ} \mathrm{C}$ compared to the calcination at $500^{\circ} \mathrm{C}$. However, in the latter case, a direct relationship cannot be established between the reduction of the $\mathrm{Ce} / \mathrm{Pr}$ parameter after calcination at $1000^{\circ} \mathrm{C}$ and the surface praseodymium enrichment, because the $\mathrm{Ce} / \mathrm{Pr}$ surface atomic ratio in $\mathrm{Ce}_{0.2} \mathrm{Pr}_{0.8} \mathrm{O}_{2-\delta}-1000$ actually corresponds to an average value of particles belonging to two different phases, due to the phase segregation that takes place in this oxide.

Another noteworthy data from Table 3 is that the sample prepared by nitrates calcination at $500^{\circ} \mathrm{C}, \mathrm{Ce}_{0.5} \mathrm{Pr}_{0.5} \mathrm{O}_{2-\delta}-500-\mathrm{CAL}$, presents a surface atomic ratio $\mathrm{Ce} / \mathrm{Pr}$ identical to the mixed oxide $\mathrm{C}_{\mathrm{e} 0.5} \mathrm{Pr}_{0.5} \mathrm{O}_{2-\delta}-1000$, prepared by co-precipitation. The greater surface praseodymium segregation in $\mathrm{Ce}_{0.5} \mathrm{Pr}_{0.5} \mathrm{O}_{2-\delta}-500$-CAL oxide compared to $\mathrm{Ce}_{0.5} \mathrm{Pr}_{0.5} \mathrm{O}_{2-\delta}-500$ is consistent with obtaining a slightly smaller apparent cubic cell parameter in $\mathrm{Ce}_{0.5} \mathrm{Pr}_{0.5} \mathrm{O}_{2-\delta}-500-\mathrm{CAL}$ oxide (Table 1 and Figure 2) and a slightly smaller shift of the Raman $\mathrm{F}_{2 \mathrm{~g}}$ band maximum to lower wavenumbers (Figure 3), due to a lower insertion of the praseodymium cation in the ceria lattice compared to the $\mathrm{Ce}_{0.5} \operatorname{Pr}_{0.5} \mathrm{O}_{2-\delta}-500$ oxide prepared by co-precipitation, in accordance with a previous study [10].

Table 3 also shows the surface reduction degrees of cerium and praseodymium, expressed as $\mathrm{Ce}^{3+}(\%)$ and $\operatorname{Pr}^{3+}(\%)$, with respect to the total quantity of each element on the surface. The important carbonation process suffered by the solid surfaces (during calcinations and storage of the samples) makes difficult the analysis of the $\mathrm{Ce}^{3+}$ and $\mathrm{Pr}^{3+}$ cations; accordingly, a considerable presence of carbon element in the surface of these oxides is observed (Table 3). For this reason, the $\mathrm{Ce}^{3+}$ and $\mathrm{Pr}^{3+}$ surface percentages are attributed both to the presence of oxygen vacancies in the oxide lattice and to the presence of surface carbonates of cerium and praseodymium with stoichiometry $\operatorname{Ln}_{2}\left(\mathrm{CO}_{3}\right)_{3^{-}}$ $\mathrm{nH}_{2} \mathrm{O}$ (where $\mathrm{Ln}$ is the lanthanide $\mathrm{Ce}$ or $\mathrm{Pr}$ ). In addition, the ultra-high vacuum conditions present during XPS analysis and the incidence of X-rays can induce some photo-reduction in the samples, reducing $\mathrm{Ce}^{4+}$ and $\mathrm{Pr}^{4+}$ cations to $\mathrm{Ce}^{3+}$ and $\mathrm{Pr}^{3+}$, respectively [29].

Considering the above comments, Table 3 shows that the estimated values of $\operatorname{Pr}^{3+}(\%)$ are always higher than those of $\mathrm{Ce}^{3+}(\%)$, which could be expected because praseodymium has a higher reduction potential than cerium $[40,41]$. Regarding the $\operatorname{Pr}^{3+}(\%)$ values, it should be noted that, for the synthesized $\mathrm{Ce}_{\mathrm{x}} \mathrm{Pr}_{1-\mathrm{x}} \mathrm{O}_{2-\delta}$, this value remains constant or suffers a slight decrease after calcining the mixed oxide at $1000^{\circ} \mathrm{C}$, compared to those mixed oxides calcined at $500^{\circ} \mathrm{C}$. However, the pure $\mathrm{PrO}_{2-\delta}$, presents an opposite trend, since the $\mathrm{Pr}^{3+}$ percentage in this case increases by $75 \%$ when 
calcining this pure oxide at $1000^{\circ} \mathrm{C}$ compared to its counterpart calcined at $500^{\circ} \mathrm{C}$. The observations collected by $\mathrm{XRD}$ after calcination at $1000^{\circ} \mathrm{C}$ are in total agreement with these trends. On the one hand, Figure 2 confirmed that when the $\mathrm{Ce}_{0.8} \operatorname{Pr}_{0.2} \mathrm{O}_{2-\delta}$ and $\mathrm{Ce}_{0.5} \mathrm{Pr}_{0.5} \mathrm{O}_{2-\delta}$ mixed oxides are calcined at $1000^{\circ} \mathrm{C}$, the average cell parameter suffers a significant decrease associated with a larger population of tetravalent cations in the oxide. Therefore, it is not expected that the $\operatorname{Pr}^{3+}$ percentage will increase after calcining these oxides at $1000^{\circ} \mathrm{C}$, as shown in Table 3. In the case of $\mathrm{Ce}_{0.2} \mathrm{Pr}_{0.8} \mathrm{O}_{2-\delta}$, the phase segregation that takes place after calcination at $1000^{\circ} \mathrm{C}$ complicates the justification that surface $\mathrm{Pr}^{3+}$ percentage has not increased after calcining the sample at a higher temperature, since this segregation leads to two phases, one of them very enriched in praseodymium, with a cell parameter very similar to that of $\operatorname{Pr}_{6} \mathrm{O}_{11}$ oxide (Table 1, JCPDS 42-1121) and a second phase with a higher cerium content than the nominal composition. However, after calcination at $1000^{\circ} \mathrm{C}$ of $\mathrm{PrO}_{2-\delta}$, it was already observed by XRD that the $\mathrm{Pr}^{3+}$ content increases in the oxide with respect to the one calcined at $500^{\circ} \mathrm{C}$, and the greater presence of $\mathrm{Pr}^{3+}$ cation on the surface of $\mathrm{PrO}_{2-\delta}-1000$ was also confirmed by XPS, although not all the $\mathrm{Pr}^{3+}$ estimated by XPS in $\mathrm{PrO}_{2-\delta}-1000$ oxide should be attributed to the presence of vacancies in the oxide due to the confirmed presence of surface carbonates in $\mathrm{Ce}_{\mathrm{x}} \mathrm{Pr}_{1-\mathrm{x}} \mathrm{O}_{2-}$ $\delta$ samples.

\subsubsection{Characterization by $\mathrm{H}_{2}-\mathrm{TPR}$}

The reducibility of $\mathrm{Ce}_{\mathrm{x}} \mathrm{Pr}_{1-\mathrm{x}} \mathrm{O}_{2-\delta}-\mathrm{T}$ oxides has been investigated by $\mathrm{H}_{2}$-TPR. Figure 5 includes the signal collected by the TCD detector during these tests as a function of the temperature for oxides calcined at $500^{\circ} \mathrm{C}$ (Figure 5a) and $1000^{\circ} \mathrm{C}$ (Figure 5b).

In the case of the $\mathrm{CeO}_{2}-500$ sample, the reduction profile of pure ceria, with a medium-high BET area, usually has two characteristic peaks [75]. The first peak, with a maximum around $590^{\circ} \mathrm{C}$, is attributed to the reduction of $\mathrm{Ce}^{4+}$ in the more superficial layers, and the second peak, between 720 and $950^{\circ} \mathrm{C}$, is caused by the bulk reduction of this oxide. This bi-modal reduction profile, where the second peak is found at such high temperatures, is indicative of relatively slow oxygen mobility from the inside of the particles to the surface in pure ceria [75].

It should be noted that all oxides were pre-treated in situ from ambient temperature up to $500^{\circ} \mathrm{C}$ under $5 \% \mathrm{O}_{2} / \mathrm{He}$ atmosphere prior to the performance of the hydrogen reduction experiments, with the aim of eliminating surface contamination present in the samples (possible presence of carbonates and $\mathrm{OH}$-surface groups). The reduction profiles of the $\mathrm{Ce}_{\mathrm{x}} \mathrm{Pr}_{1-\mathrm{x}} \mathrm{O}_{2-\delta^{-}} 1000$ mixed oxides, pure $\mathrm{PrO}_{2-\delta^{-}}$ 1000 oxide and some oxides calcined at $500^{\circ} \mathrm{C}$, such as $\mathrm{Ce}_{0.8} \mathrm{Pr}_{0.2} \mathrm{O}_{2-\delta}-500$, show the presence of a 
weak shoulder in the temperature range between $250^{\circ} \mathrm{C}$ and $400^{\circ} \mathrm{C}$ that could be associated with the desorption/reduction of part of this surface contamination that the pre-treatment was not able to eliminate, or to very labile surface oxygen species. This weak shoulder is also seen in the reduction profile of pure $\mathrm{CeO}_{2}-500$ oxide but in the temperature range between $400^{\circ} \mathrm{C}$ and $500^{\circ} \mathrm{C}$.

Doping pure ceria with 20 at\% of praseodymium $\left(\mathrm{Ce}_{0.8} \operatorname{Pr}_{0.2} \mathrm{O}_{2-\delta}-500\right)$ shows a notable improvement in the reducibility of the mixed oxide obtained. In this case, the reduction peak at high temperatures, characteristic of the bulk reduction of pure ceria, has completely disappeared.

As the praseodymium content in the mixed oxide increases $\left(\mathrm{Ce}_{0.5} \operatorname{Pr}_{0.5} \mathrm{O}_{2-\delta^{-}} 500\right.$ and $\mathrm{Ce}_{0.2} \operatorname{Pr}_{0.8} \mathrm{O}_{2-}$ ${ }_{\delta}$-500), the global hydrogen consumption in the reduction test is also increased, with the transformation of the double-peak profile present in $\mathrm{CeO}_{2}-500$ by a more continuous profile, where the hydrogen consumption starts at lower temperatures and ends at around $550^{\circ} \mathrm{C}$. However, the reduction profile of $\mathrm{Ce}_{0.2} \mathrm{Pr}_{0.8} \mathrm{O}_{2-\delta}-500$ does not reveal a real continuity, since this profile shows two different peaks. This could be due to the possible presence of more than one phase in this oxide, as the XRD analysis of this sample pointed out.

Comparing the $\mathrm{Ce}_{0.5} \operatorname{Pr}_{0.5} \mathrm{O}_{2-8}-500$ reduction profile with its counterpart prepared by the nitrate calcination method $\left(\mathrm{Ce}_{0.5} \mathrm{Pr}_{0.5} \mathrm{O}_{2-\delta}-500-\mathrm{CAL}\right)$, there are no significant differences in the reduction profiles of both oxides. In both cases, the patterns are quite symmetrical, with the beginning and ending of the hydrogen consumption at virtually identical temperatures. In good agreement with the literature, Logan et al. [35] obtained a reduction profile for a $\mathrm{Ce}_{0.45} \operatorname{Pr}_{0.55} \mathrm{O}_{\mathrm{x}}$ composition, prepared by co-precipitation method with oxalic acid and calcining the corresponding oxalates obtained at $750^{\circ} \mathrm{C}$, very similar to the reduction profile presented in Figure $5 \mathrm{a}$ for $\mathrm{Ce}_{0.5} \mathrm{Pr}_{0.5} \mathrm{O}_{2-\delta}-500$ composition.

The comparison between the reduction profiles of $\mathrm{PrO}_{2-\delta}-500$ and $\mathrm{CeO}_{2}-500$ pure oxides reveals the largest differences, confirming the greater reducibility of $\mathrm{Pr}^{4+}$ cation at lower temperatures, as well as a much higher global consumption of hydrogen, showing that a greater number of cations can be reduced to the trivalent oxidation state. Logan et al. [35] and Krishna et al. [47] published reduction profiles for pure praseodymia very similar to the one presented in Figure 5a. In fact, at $520^{\circ} \mathrm{C}$, the $\mathrm{PrO}_{2-8}-500$ reduction profile has no longer hydrogen consumption; while at this temperature $\mathrm{CeO}_{2}-500$ oxide has not yet reached the maximum of the first peak of its bi-modal profile. In this sense, Logan et al. [35] observed that the $\mathrm{H}_{2}$ consumption estimation in a $\mathrm{H}_{2}$-TPR experiment of pure ceria was far from that corresponding to a stoichiometric reduction from $\mathrm{CeO}_{2}$ to $\mathrm{Ce}_{2} \mathrm{O}_{3}$. In contrast, the hydrogen consumed in the $\mathrm{H}_{2}$-TPR of $\operatorname{Pr}_{6} \mathrm{O}_{11}$ oxide was very close to that needed for the reduction to $\mathrm{Pr}_{2} \mathrm{O}_{3}$, which in turn reveals that for a total reduction of $\mathrm{CeO}_{2}$ to $\mathrm{Ce}_{2} \mathrm{O}_{3}$, 
much more drastic reducing conditions are required than those for the reduction from $\operatorname{Pr}_{6} \mathrm{O}_{11}$ to $\operatorname{Pr}_{2} \mathrm{O}_{3}$. These observations derive from the better reducibility of the $\mathrm{Pr}^{4+}$ cation compared to the $\mathrm{Ce}^{4+}$ cation [41].

The $\mathrm{CeO}_{2}-1000$ profile only contains the peak corresponding to the bulk oxide reduction, where the surface reduction peak has disappeared. This is consistent with the low BET surface area of this sample. However, the presence of praseodymium in oxides calcined at $1000^{\circ} \mathrm{C}$ leads to reduction profiles with higher hydrogen consumption and shifted to lower temperatures than $\mathrm{CeO}_{2}-1000$ and even $\mathrm{CeO}_{2}-500$.

The most relevant difference between $\mathrm{Ce}_{\mathrm{x}} \operatorname{Pr}_{1-\mathrm{x}} \mathrm{O}_{2-\delta}-500$ and $\mathrm{Ce}_{\mathrm{x}} \operatorname{Pr}_{1-\mathrm{x}} \mathrm{O}_{2-\delta}-1000$ reduction profiles with $0<\mathrm{x}<1$ is the shift of the profiles to higher temperatures when the calcination temperature increases. This observation indicates that both the surface and bulk regions of these oxides become somewhat more difficult to reduce as the calcination temperature increases, possibly due to the significant loss in BET surface area and the increase in average crystal sizes. However, even though these oxides calcined at $1000^{\circ} \mathrm{C}$ have a very low BET area, they have a considerable $\mathrm{H}_{2}$ consumption. The pure $\mathrm{PrO}_{2-\delta}-1000$ oxide reveals the highest consumption of hydrogen among those calcined at $1000^{\circ} \mathrm{C}$, which indicates the remarkable praseodymium reducibility in this oxide, both calcined at $500^{\circ} \mathrm{C}$ and $1000^{\circ} \mathrm{C}$.

Thus, as published by Luo et al. [60], the praseodymium doping of ceria leads to a greater hydrogen reduction, which occurs at lower temperatures. This is due to the increased presence of oxygen vacancies in the lattice, as indicated by Raman spectroscopy, and the easier formation of reactive oxygen species.

Additional quantifications regarding $\mathrm{H}_{2}$ consumption of the samples and the corresponding discussion are included in the Supplementary Material.

\subsection{Catalytic activity studies}

The $\mathrm{NO}_{2}$ production activity is highly significant to initiate and propagate the soot combustion activity under $\mathrm{NOx} / \mathrm{O}_{2}$ at low and medium temperatures. For this reason, it will be discussed first. Secondly, the soot combustion activity under $\mathrm{NOx} / \mathrm{O}_{2}$ will be presented and finally in an attempt to "split" and understand the contributions of the two relevant mechanisms: $\mathrm{NO}_{2}$-assisted soot combustion and "active-oxygen"- assisted soot combustion 
mechanisms, (as widely stated in the literature $[10,21,25,51,76]$ the soot combustion curves under $\mathrm{O}_{2}$ will be discussed.

\subsubsection{Catalytic $\mathrm{NO}$ oxidation tests to $\mathrm{NO}_{2}$}

Given the relevance of $\mathrm{NO}_{2}$ production for the justification of the catalytic activity in soot combustion under $\mathrm{NOx} / \mathrm{O}_{2}$ atmosphere of cerium oxides and cerium-based mixed oxides, especially for those oxides whose maximum $\mathrm{NO}_{2}$ production takes place at low or medium temperatures, the following Figure 6 shows the $\mathrm{NO}_{2}$ formation profiles as a function of temperature, obtained from the $\mathrm{NO}$ oxidation reaction in the presence of $\mathrm{O}_{2}$, for the $\mathrm{Ce}_{\mathrm{x}} \mathrm{Pr}_{1-\mathrm{x}} \mathrm{O}_{2-\delta}$ oxides studied in this work.

It is important to note from Figure 6 that as the praseodymium content increases in the $\mathrm{Ce}_{\mathrm{x}} \operatorname{Pr}_{1-}$ ${ }_{\mathrm{x}} \mathrm{O}_{2-\delta}-\mathrm{T}$ formulation, the $\mathrm{NO}_{2}$ production is higher and the maximum $\mathrm{NO}_{2}$ production is shifted to lower temperatures. The most notable difference is observed between $\mathrm{CeO}_{2-500}$ and $\mathrm{Ce}_{0.8} \operatorname{Pr}_{0.2} \mathrm{O}_{2-\delta^{-}}$ 500 , showing an increase in the maximum $\mathrm{NO}_{2}$ production from $24 \%$ to $39 \%$ when the cerium oxide is doped with only a 20 at $\%$ of praseodymium.

Therefore, it seems evident that praseodymium is much more active for $\mathrm{NO}$ oxidation to $\mathrm{NO}_{2}$ than cerium. In addition, it could be thought that part of the $\mathrm{NO}_{2}$ production improvement by doping $\mathrm{CeO}_{2}-500$ with 20 at\% of praseodymium is also due to the increase in BET surface area (from 57 to $70 \mathrm{~m}^{2} / \mathrm{g}$ ). However, when pure $\mathrm{CeO}_{2}-500$ oxide is doped with 50 at $\%$ and 80 at $\%$ of praseodymium $\left(\mathrm{Ce}_{0.5} \mathrm{Pr}_{0.5} \mathrm{O}_{2-\delta}-500\right.$ and $\mathrm{Ce}_{0.2} \mathrm{Pr}_{0.8} \mathrm{O}_{2-\delta}-500$, respectively), the maximum $\mathrm{NO}_{2}$ production is similar or slightly higher than that of $\mathrm{Ce}_{0.8} \mathrm{Pr}_{0.2} \mathrm{O}_{2-\delta}-500$, showing the previous mixed oxides much smaller BET surface areas ( 27 and $17 \mathrm{~m}^{2} / \mathrm{g}$, respectively). Finally, pure $\mathrm{PrO}_{2-\delta}-500$ is characterized by an increased $\mathrm{NO}_{2}$ production (maximum $\mathrm{NO}_{2}$ production of $48 \%$ at $375^{\circ} \mathrm{C}$ ). All these experimental evidences reveal that the progressive loading of Pr onto ceria does not yield a gradual and regular trend of increase in activity, which can be explained by a balance among more presence of Pr reducible cation but, in general, lower BET areas than the $\mathrm{Ce}_{0.8} \operatorname{Pr}_{0.2} \mathrm{O}_{2}$ composition, which makes difficult the establishment of correlations.

It can also be seen that, as the praseodymium content of $\mathrm{Ce}_{\mathrm{x}} \operatorname{Pr}_{1-\mathrm{x}} \mathrm{O}_{2-\delta_{-}^{-}} 500$ oxides increases, the activity appears at lower temperatures, in the range of $50^{\circ} \mathrm{C}$ to $250^{\circ} \mathrm{C}$. This was not previously detected for pure ceria or for mixed $\mathrm{Ce}_{\mathrm{x}} \mathrm{Zr}_{1-\mathrm{x}} \mathrm{O}_{2}$ oxides. In this temperature range, the peak of $\mathrm{NO}_{2}$ formation at $150^{\circ} \mathrm{C}$ of pure $\mathrm{PrO}_{2-8}-500$ is noticeable, with a maximum $\mathrm{NO}_{2}$ production of $16 \%$. This $\mathrm{NO}_{2}$ production by $\mathrm{Ce}_{\mathrm{x}} \mathrm{Pr}_{1-\mathrm{x}} \mathrm{O}_{2-\delta}-500$ oxides with $\mathrm{x}=0.5,0.2$ and 0 in the range of $50^{\circ} \mathrm{C}$ to $250^{\circ} \mathrm{C}$ is 
due to NOx species desorption, mainly as $\mathrm{NO}_{2}$, that were previously adsorbed on the surface at very low temperatures.

The calcination at $1000^{\circ} \mathrm{C}$ of $\mathrm{Ce}_{\mathrm{x}} \mathrm{Pr}_{1-\mathrm{x}} \mathrm{O}_{2-\delta}$ oxides causes the loss of catalytic activity in the low temperature range (between $50^{\circ} \mathrm{C}$ and $250^{\circ} \mathrm{C}$ ), with onset $\mathrm{NO}_{2}$ production at higher temperatures. In addition, the catalytic $\mathrm{NO}_{2}$ production is diminished, as expected, by the severe sintering effect suffered by this type of oxides. However, it is noteworthy that $\mathrm{Ce}_{0.2} \mathrm{Pr}_{0.8} \mathrm{O}_{2-\delta}-1000$ and $\mathrm{PrO}_{2-\delta}-1000$ oxides, with BET surface areas of only 4 and $2 \mathrm{~m}^{2} / \mathrm{g}$ respectively, present a greater capacity for NO oxidation than pure $\mathrm{CeO}_{2}$ calcined at $500^{\circ} \mathrm{C}$, thus indicating the accentuated activity promoted by praseodymium, with respect to cerium, in this oxidation reaction.

This high catalytic activity in the $\mathrm{NO}$ oxidation to $\mathrm{NO}_{2}$ reaction, after calcination at such a high temperature, $1000^{\circ} \mathrm{C}$, had never been obtained either in $\mathrm{Ce}_{\mathrm{x}} \mathrm{Zr}_{1-\mathrm{x}} \mathrm{O}_{2}$ mixed oxides or in pure ceria, which agrees the interest of replacing the zirconium doping cation by praseodymium in the cerium oxide. These results are supported by the energy values of the $\mathrm{Ce}-\mathrm{O}$ bond, which are higher than those of the $\mathrm{Pr}-\mathrm{O}$ bond [38], because the ionization potential of $\mathrm{Ce}^{3+}$ is $2.22 \mathrm{eV}$, lower than the corresponding ionization potential value of the $\operatorname{Pr}^{3+}$ cation [77]. Due to this, the incorporation of praseodymium into the ceria lattice increases both the creation of oxygen vacancies and the presence of more labile oxygen species [38]. This is the reason why the $\mathrm{NO}$ oxidation to $\mathrm{NO}_{2}$ profiles obtained were improved compared to those of $\mathrm{Ce}_{\mathrm{x}} \mathrm{Zr}_{1-\mathrm{x}} \mathrm{O}_{2}$.

It is interesting to point out that this is one of the most interesting findings of this work, since it will have a very positive influence on the soot combustion activity under $\mathrm{NOx} / \mathrm{O}_{2}$, considering that these catalysts will be submitted to strong thermal shock under real applications (diesel exhaust). Complementarily, the influence of Pr loading on the NO oxidation activity can be more clearly seen in this set of samples, since the enhancement in activity is gradual with the Pr content (see Figure 6b). Probably, this can be due to the fact that all the catalysts calcined at $1000^{\circ} \mathrm{C}$ present very low and comparable BET surface areas. Therefore, the higher presence of a more reducible cation (Pr) leads to higher catalytic activities.

In addition, the higher reducibility of the $\operatorname{Pr}^{4+}$ cation compared to the $\mathrm{Ce}^{4+}$ cation explains the different $\mathrm{H}_{2}$-TPR profiles presented previously. Thus, in the temperature range between $360^{\circ} \mathrm{C}$ and $430^{\circ} \mathrm{C}$, where the maximum $\mathrm{NO}_{2}$ production for $\mathrm{Ce}_{\mathrm{x}} \mathrm{Pr}_{1-\mathrm{x}} \mathrm{O}_{2-\delta}-500$ oxides is reached, the $\mathrm{H}_{2}$-TPR profiles of the praseodymium-containing oxides show a significant $\mathrm{H}_{2}$ consumption, while $\mathrm{CeO}_{2}-500$ has barely begun its surface reduction at $450^{\circ} \mathrm{C}$. In this respect, Sinev et al. [38] were able to observe by XPS that in the case of $\mathrm{Ce}_{\mathrm{x}} \mathrm{Pr}_{1-\mathrm{x}} \mathrm{O}_{2-\delta}$ mixed oxides, both in a predominantly oxidizing or a reducing 
environment, the surface layers present $\mathrm{Ce}^{4+}$ ions as predominant, while the praseodymium ions were partially reduced to the trivalent state. This fact again justifies that the larger the praseodymium content, the higher the mixed oxide activity in the $\mathrm{NO}$ oxidation to $\mathrm{NO}_{2}$.

The results presented so far show a good agreement with the literature, regarding the praseodymium-doping effect in the ceria lattice. Pu et al. [78] investigated the doping effect with praseodymium and copper on ceria, preparing these materials using the sol-gel method. It was observed that the $\mathrm{Ce}_{0.9} \mathrm{Pr}_{0.1} \mathrm{O}_{2-\delta}$ had a higher catalytic activity in the $\mathrm{CO}$ oxidation reaction than that of pure ceria, which in turn was related to the higher oxygen vacancies concentration, as a result of the $\mathrm{Ce}^{4+}$ cations substitution by $\mathrm{Pr}^{3+} / \mathrm{Pr}^{4+}$ cations in the ceria framework. In total agreement with the previous work, Somacescu et al. [37] studied the catalytic activity of methane oxidation with mixed mesoporous $\mathrm{Ce}_{\mathrm{x}} \mathrm{Pr}_{1-\mathrm{x}} \mathrm{O}_{2-\delta}$ oxides with various compositions, prepared by using an ionic surfactant. It could be demonstrated a greater catalytic activity for all the $\mathrm{Ce}_{\mathrm{x}} \mathrm{Pr}_{1-\mathrm{x}} \mathrm{O}_{2-\delta}$ mixed oxides synthesized with respect to pure cerium oxide.

Finally, the $\mathrm{NO}_{2}$ formation profiles obtained as a function of temperature for both $\mathrm{Ce}_{\mathrm{x}} \operatorname{Pr}_{1-\mathrm{x}} \mathrm{O}_{2-\delta}$ (Figure 6) and $\mathrm{Ce}_{\mathrm{x}} \mathrm{Zr}_{1-\mathrm{x}} \mathrm{O}_{2}$ oxides (see previously published results using these mixed oxides [57]) confirm that ceria doping with praseodymium leads to catalytic capabilities in the NO oxidation to $\mathrm{NO}_{2}$ under $\mathrm{O}_{2}$ atmosphere much more efficient than when doping with zirconium. In fact, the best $\mathrm{Ce}_{\mathrm{x}} \mathrm{Zr}_{1-\mathrm{x}} \mathrm{O}_{2}$ mixed oxide prepared to date, $\mathrm{Ce}(4+)_{0.8} \mathrm{Zr}_{0.2} \mathrm{O}_{2}-500$ [57], starts showing some catalytic activity from $250^{\circ} \mathrm{C}$, generating a $\mathrm{NO}_{2}$ maximum of $26 \%$ at $429^{\circ} \mathrm{C}$, while the $\mathrm{Ce}_{\mathrm{x}} \mathrm{Pr}_{1-\mathrm{x}} \mathrm{O}_{2-\delta}-500$ mixed oxides studied in the present work show a significant $\mathrm{NO}_{2}$ formation at $50^{\circ} \mathrm{C}$, with a maximum level around $40-48 \%$ at temperatures lower than $430^{\circ} \mathrm{C}$.

\subsubsection{Catalytic soot combustion tests under $\mathrm{NOx} / \mathrm{O}_{2}$ and $\mathrm{O}_{2} / \mathrm{N}_{2}$}

In this section, the performance of $\mathrm{Ce}_{\mathrm{x}} \operatorname{Pr}_{1-\mathrm{x}} \mathrm{O}_{2-\delta}$ catalysts calcined at $500^{\circ} \mathrm{C}$ and $1000^{\circ} \mathrm{C}$ towards soot combustion is studied by using the loose contact mode between catalyst and soot. In addition, the catalytic behavior of these oxides in both $\mathrm{NOx} / \mathrm{O}_{2}$ and $\mathrm{O}_{2} / \mathrm{N}_{2}$ atmospheres is analyzed. It should be remarked that a tentative correlation and discussion between the characterization results and the catalytic activity of the catalysts is carried out in this subsection, due to its complexity, since several factors affect the catalytic behavior. 
Figure 7 shows the soot conversion profiles of $\mathrm{Ce}_{x} \operatorname{Pr}_{1-\mathrm{x}} \mathrm{O}_{2-\delta}-500$ catalysts, obtained in temperature-programmed experiments under $\mathrm{NO}_{\mathrm{x}} / \mathrm{O}_{2}$ atmosphere (Figure $7 \mathrm{a}$ ), as well as in $\mathrm{O}_{2} / \mathrm{N}_{2}$ atmosphere (Figure 7b).

All the prepared catalysts decrease the oxidation temperature of soot compared to the noncatalyzed oxidation, thus obtaining better catalytic behavior when these tests are carried out in the presence of NOx (Figure 7a). This aspect was also seen in the catalytic study of soot combustion using $\mathrm{Ce}_{\mathrm{x}} \mathrm{Zr}_{1-\mathrm{x}} \mathrm{O}_{2}$ oxides [57]. In order to facilitate the comparison of the catalytic activity in the two atmospheres studied, the T50\% values (see Experimental Section) of the $\mathrm{Ce}_{\mathrm{x}} \mathrm{Pr}_{1-\mathrm{x}} \mathrm{O}_{2-\delta}-\mathrm{T}$ soot combustion tests carried out under both $\mathrm{NOx} / \mathrm{O}_{2}$ and $\mathrm{O}_{2} / \mathrm{N}_{2}$ have been included in Table 4. In addition, this table also shows the real selectivity values for $\mathrm{CO}$ formation (see Experimental Section), as it is the undesirable product in soot combustion.

Looking more closely at the soot conversion profiles of $\mathrm{Ce}_{\mathrm{x}} \mathrm{Pr}_{1-\mathrm{x}} \mathrm{O}_{2-\delta^{-}}-500$ catalysts obtained under $\mathrm{NOx} / \mathrm{O}_{2}$ atmosphere (Figure $7 \mathrm{a}$ ), the catalytic order of the oxides varies with temperature. Thus, at low temperatures (ranging from 300 to $450^{\circ} \mathrm{C}$ ), there is a good agreement between the NO oxidation capacity to $\mathrm{NO}_{2}$ and the catalytic activity towards soot combustion. In the latter case, the following trend is found:

$\mathrm{PrO}_{2-\delta}-500>\mathrm{Ce}_{0.2} \mathrm{Pr}_{0.8} \mathrm{O}_{2-\delta}-500 \approx \mathrm{Ce}_{0.5} \mathrm{Pr}_{0.5} \mathrm{O}_{2-\delta}-500-\mathrm{CAL}>\mathrm{Ce}_{0.5} \mathrm{Pr}_{0.5} \mathrm{O}_{2-\delta^{-}} 500>\mathrm{Ce}_{0.8} \mathrm{Pr}_{0.2} \mathrm{O}_{2-\delta^{-}}$ $500>\mathrm{CeO}_{2}-500$

However, at higher temperatures where the soot conversion percentage is higher (between $500^{\circ} \mathrm{C}$ and $650^{\circ} \mathrm{C}$ ), the same catalytic order is not obtained in $\mathrm{NOx} / \mathrm{O}_{2}$ atmosphere, since the most active catalyst in this case is the $\mathrm{Ce}_{0.5} \mathrm{Pr}_{0.5} \mathrm{O}_{2-\delta}-500-\mathrm{CAL}$ and not the pure $\mathrm{PrO}_{2-\delta}-500$. Although, the catalytic differences between the $\mathrm{Ce}_{\mathrm{x}} \mathrm{Pr}_{1-\mathrm{x}} \mathrm{O}_{2-\delta}-500$ oxides with $\mathrm{x}=0.5,0.2$ and 0 in this temperature range are very small. Thus, in $\mathrm{NOx} / \mathrm{O}_{2}$ atmosphere, the $\mathrm{Ce}_{0.5} \mathrm{Pr}_{0.5} \mathrm{O}_{2-\delta}-500-\mathrm{CAL}$ is always slightly higher in activity than its counterpart prepared by co-precipitation $\left(\mathrm{Ce}_{0.5} \operatorname{Pr}_{0.5} \mathrm{O}_{2-\delta}-500\right)$, which is relevant in terms of the sustainability and economy of the nitrate calcination method, as it requires only the precursor cerium and praseodymium salts as reagents. An interesting analogy is that $\mathrm{Ce}_{0.5} \operatorname{Pr}_{0.5} \mathrm{O}_{2-\delta}$ composition was also optimal in a previous catalytic study [46] in which the activity and stability of $\mathrm{Ce}_{\mathrm{x}} \mathrm{Pr}_{1-\mathrm{x}} \mathrm{O}_{2-\delta}$ mixed oxides was evaluated with $\mathrm{x}=0.8,0.5$ and 0.2 together with the pure $\mathrm{CeO}_{2}$ and $\mathrm{PrO}_{2-\delta}$ oxides in the combustion of 1,2-dichloroethane. As a summary, a synergistic effect regarding Pr-doping onto ceria (as the optimal composition) might be seen for this formulation. It can be tentatively said that a combination of moderate surface area (because the following Pr-rich 
composition, $\mathrm{Ce}_{0.2} \mathrm{Pr}_{0.8} \mathrm{O}_{2}$, presents a lowering in surface area) with good oxygen mobility (see Figure S2) could be responsible of this trend.

The $\mathrm{Ce}_{0.5} \operatorname{Pr}_{0.5} \mathrm{O}_{2-\delta}-500-\mathrm{CAL}$ mixed oxide presents a soot combustion catalytic behavior under $\mathrm{NOx} / \mathrm{O}_{2}$ slightly superior to the analogous oxide prepared by co-precipitation $\left(\mathrm{Ce}_{0.5} \operatorname{Pr}_{0.5} \mathrm{O}_{2-8}-500\right)$. It seems to be due to the $\mathrm{NO}_{2}$ production in the blank experiment, which was also slightly higher in the oxide prepared by nitrate calcination that, in turn, can be attributed to its higher surface enrichment in praseodymium revealed by the XPS technique (Table 3 ).

On the other hand, the catalytic activity order of $\mathrm{Ce}_{x} \mathrm{Pr}_{1-\mathrm{x}} \mathrm{O}_{2-\delta}-500$ oxides in this reaction is not the same under $\mathrm{O}_{2} / \mathrm{N}_{2}$ than under $\mathrm{NOx} / \mathrm{O}_{2}$ atmospheres. Thus, when the soot combustion takes place under $\mathrm{O}_{2} / \mathrm{N}_{2}$ (without the presence of $\mathrm{NOx}$ ), pure $\mathrm{PrO}_{2-\delta}-500$ and the mixed oxides that had a worse praseodymium insertion in the ceria lattice, $\mathrm{Ce}_{0.2} \mathrm{Pr}_{0.8} \mathrm{O}_{2-\delta}-500$ and $\mathrm{Ce}_{0.5} \mathrm{Pr}_{0.5} \mathrm{O}_{2-\delta}-500-\mathrm{CAL}$, exhibit a very similar activity, surpassing the activity of pure $\mathrm{CeO}_{2}-500$. However, $\mathrm{Ce}_{0.8} \operatorname{Pr}_{0.2} \mathrm{O}_{2-\delta}-500$ and $\mathrm{Ce}_{0.5} \operatorname{Pr}_{0.5} \mathrm{O}_{2-\delta}-500$ have the highest activity under $\mathrm{O}_{2} / \mathrm{N}_{2}$, but $\mathrm{Ce}_{0.5} \operatorname{Pr}_{0.5} \mathrm{O}_{2-\delta}$ composition is slightly more active, as it also happened under $\mathrm{NOx} / \mathrm{O}_{2}$ atmosphere. Nevertheless, the difference in this case is that under $\mathrm{O}_{2} / \mathrm{N}_{2}$ atmosphere, the co-precipitation method is more favorable than the nitrate calcination method (Figure $7 \mathrm{~b}$ and Table 4). These observations tentatively indicate that the presence of both cerium and praseodymium has a synergistic effect on the combustion of carbonaceous material under these conditions $\left(\mathrm{O}_{2} / \mathrm{N}_{2}\right.$ atmosphere $)$ and, besides, the fact that the $\mathrm{Ce}_{0.8} \mathrm{Pr}_{0.2} \mathrm{O}_{2-\delta}$ is the formulation with the highest BET surface area. In this respect, it is described in the literature [38] that the solid-gas transfer of oxygen is faster in a ceria-praseodymia mixed oxide than in pure praseodymia $\left(\mathrm{Ce}_{0.45} \mathrm{Pr}_{0.55} \mathrm{O}_{2-\delta}\right.$ versus $\left.\mathrm{PrO}_{2-\delta}\right)$. The comparison of temperature profiles and isothermal reoxidation kinetics carried out by Sinev et al. [38] showed that the addition of cerium to pure praseodymia increases the mobility of oxygen anions in the lattice. One of the reasons that these authors point out to explain this observation is that while the reduced praseodymium cations $\left(\operatorname{Pr}^{3+}\right)$ appear to be responsible of oxygen activation at the surface, both redox pairs $\left(\mathrm{Pr}^{3+} / \mathrm{Pr}^{4+}\right.$ and $\left.\mathrm{Ce}^{3+} / \mathrm{Ce}^{4+}\right)$ participate in the charge transfer process within the oxide.

The soot combustion reaction by itself under $\mathrm{O}_{2} / \mathrm{N}_{2}$ (without $\mathrm{NOx}$ ) should be considered as a test that provides information on the capacity of these oxides for the production and transfer of active oxygen. Thus, the final catalytic result in the soot combustion under $\mathrm{O}_{2} / \mathrm{N}_{2}$ is influenced by three main factors:

(i) The ability to produce surface/subsurface active oxygen species.

(ii) The ability to transfer these active species to the soot surface. 
(iii) The ability of the oxide to re-incorporate oxygen from the gas phase into the lattice with the aim of recovering the oxygen released to the soot and to continue producing surface/subsurface active oxygen species.

Thus, during the catalytic soot combustion, the oxide undergoes reduction processes when it transfers active oxygen species to the soot surface and oxidation takes place when it takes oxygen from the gas phase.

However, in the temperature-programmed $\mathrm{H}_{2}$ reduction tests, the experimental conditions are very different. In this case, the atmosphere is strongly reducing, so these tests only reveal information on the oxides reduction, regardless of the oxide capacity for reoxidation. Meanwhile, the latter is also relevant for the $\mathrm{O}_{2} / \mathrm{N}_{2}$ soot combustion test. For this reason, the catalytic order in soot combustion under $\mathrm{O}_{2} / \mathrm{N}_{2}$ atmosphere in $\mathrm{Ce}_{\mathrm{x}} \mathrm{Pr}_{1-\mathrm{x}} \mathrm{O}_{2-\delta^{-}}-500$ oxides does not match with the reduction profiles $\left(\mathrm{H}_{2-}\right.$ TPR tests, Figure 5).

With respect to these soot combustion tests under $\mathrm{O}_{2} / \mathrm{N}_{2}$, it was already analyzed in a previous work [57] that at high temperatures, where soot combustion under $\mathrm{O}_{2} / \mathrm{N}_{2}$ occurs, a good insertion of zirconium in the ceria lattice, and therefore, an acceptable oxygen mobility in the sub-surface and bulk, were key to explain the catalytic activity of $\mathrm{Ce}_{\mathrm{x}} \mathrm{Zr}_{1-\mathrm{x}} \mathrm{O}_{2}$ in loose contact mode (between soot and catalyst). In this sense, for $\mathrm{Ce}_{\mathrm{x}} \mathrm{Pr}_{1-\mathrm{x}} \mathrm{O}_{2-\delta}$, it also appears that the insertion of the doping cation into the ceria framework is a key factor to justify the catalytic soot combustion activity under $\mathrm{O}_{2} / \mathrm{N}_{2}$. Therefore, it is shown in Figure $7 \mathrm{~b}$ that $\mathrm{Ce}_{0.8} \mathrm{Pr}_{0.2} \mathrm{O}_{2-\delta}-500$ oxide, despite having less praseodymium content, presents a catalytic activity almost identical to that of $\mathrm{Ce}_{0.5} \operatorname{Pr}_{0.5} \mathrm{O}_{2-\delta}-500$, since this composition $\left(\mathrm{Ce}_{0.8} \mathrm{Pr}_{0.2} \mathrm{O}_{2-\delta}-500\right)$ presents the best praseodymium insertion into the ceria structure achieved, as indicated by the values of the apparent cubic cell parameters obtained by XRD (Figure 2). In the same way, the greater catalytic activity under $\mathrm{O}_{2} / \mathrm{N}_{2}$ presented by the $\mathrm{Ce}_{0.5} \mathrm{Pr}_{0.5} \mathrm{O}_{2-\delta}-500$, prepared by co-precipitation, is reasonable compared to its counterpart prepared by nitrate calcination. This fact is due to the worse praseodymium insertion into the ceria structure obtained with $\mathrm{Ce}_{0.5} \mathrm{Pr}_{0.5} \mathrm{O}_{2-\delta}-500-\mathrm{CAL}$, which has led to a worse oxygen mobility in this oxide compared to $\mathrm{Ce}_{0.5} \mathrm{Pr}_{0.5} \mathrm{O}_{2-\delta}-500$ prepared by co-precipitation, and therefore, to a worse activity in $\mathrm{O}_{2} / \mathrm{N}_{2}$.

In this sense, the justification of the trends observed in Figure $7 \mathrm{~b}$ is not simple, as there are several variables that converge simultaneously. The most important parameters for this reaction under $\mathrm{O}_{2} / \mathrm{N}_{2}$ (without the presence of NOx) are, firstly, a good praseodymium insertion into the ceria lattice, and secondly, the praseodymium content in the mixed oxide. Finally, at high soot conversions, since less and less soot remains in the reactor, BET surface area (and definitively particle size), seems 
to be relevant under loose contact, since more and more points of contact among soot and catalyst are being decreased. This can be a tentative explanation to account for why $\mathrm{Ce}_{0.8} \operatorname{Pr}_{0.2} \mathrm{O}_{2-\delta}$ is one of the best formulations.

The $\mathrm{Ce}_{\mathrm{x}} \mathrm{Pr}_{1-\mathrm{x}} \mathrm{O}_{2-\delta}-500$ oxides show quite low selectivity values of $\mathrm{CO}$ formation (Table 4), all of them lower than $17 \%$. In addition, these values reveal a lower CO selectivity under $\mathrm{O}_{2} / \mathrm{N}_{2}$ than under $\mathrm{NOx} / \mathrm{O}_{2}$ atmosphere. Two hypotheses are presented to explain this situation. The first one is based on the fact that the surface oxygen complexes (SOCs) formed on soot as well as the decomposition of these SOCs to $\mathrm{CO} / \mathrm{CO}_{2}$ depend on the type of atmosphere in which the combustion takes place (NOx/O $/ \mathrm{O}_{2}$ versus $\mathrm{O}_{2} / \mathrm{N}_{2}$ ) and on the temperature. This hypothesis is supported by the slightly higher selectivity to $\mathrm{CO}$ in the soot combustion without catalyst when it takes place under $\mathrm{NOx} / \mathrm{O}_{2}$ compared to that under $\mathrm{O}_{2} / \mathrm{N}_{2}$ (63\% versus $60 \%$ respectively). The second hypothesis is related to the known catalytic capacity of cerium-based oxides for the CO oxidation [24, 32-34, 60, 78], so the presence of NOx in the atmosphere could cause a certain inhibition of the $\mathrm{CO}$ oxidation reaction due to the formation of nitrite/nitrate surface groups on the catalyst, that would prevent to a certain degree the adsorption of the $\mathrm{CO}$ released by soot for its complete oxidation to $\mathrm{CO}_{2}$.

Additionally, it should be noted that, under loose contact conditions between catalyst and soot, both under $\mathrm{NOx} / \mathrm{O}_{2}$ and $\mathrm{O}_{2} / \mathrm{N}_{2}$ atmosphere, the catalytic activity for soot combustion obtained with the best $\mathrm{Ce}_{\mathrm{x}} \mathrm{Pr}_{1-\mathrm{x}} \mathrm{O}_{2-\delta}-500$ mixed oxide is always higher than that of the best mixed oxide derived from a previous study, carried out by us with ceria-zirconia mixed oxides [57].

Finally, the effect of the calcination temperature on the $\mathrm{Ce}_{x} \operatorname{Pr}_{1-\mathrm{x}} \mathrm{O}_{2-\delta}$ catalytic activity towards soot combustion was studied. Figure 8 shows the soot conversion profiles of both $\mathrm{NOx} / \mathrm{O}_{2}$ atmosphere (Figure $8 \mathrm{a}$ ) and $\mathrm{O}_{2} / \mathrm{N}_{2}$ atmosphere (Figure $8 \mathrm{~b}$ ) of these oxides calcined at $1000^{\circ} \mathrm{C}$.

The catalytic activity for soot combustion of $\mathrm{Ce}_{\mathrm{x}} \operatorname{Pr}_{1-\mathrm{x}} \mathrm{O}_{2-\delta}$ oxides, when calcined at $1000^{\circ} \mathrm{C}$ (Figure 8 ) is very limited, according to Krishna et al. [19]. These authors carried out complementary soot combustion tests establishing an intimate (tight) contact between catalyst and soot under $\mathrm{O}_{2}$ atmosphere, in order to observe catalytic differences between $\mathrm{CeO}_{2}$ and $\mathrm{Ce}_{0.9} \operatorname{Pr}_{0.1} \mathrm{O}_{2-\delta}$ oxides calcined at $1000^{\circ} \mathrm{C}$, demonstrating the greater catalytic activity of $\mathrm{Ce}_{0.9} \mathrm{Pr}_{0.1} \mathrm{O}_{2-\delta}-1000$ mixed oxide under $\mathrm{O}_{2}$ when there are tight contact conditions.

In our case, even if catalyst and soot are mixed under loose contact, a slightly higher activity can be observed in the soot conversion curves of the praseodymium-containing catalysts $\left(\mathrm{Ce}_{\mathrm{x}} \mathrm{Pr}_{1-\mathrm{x}} \mathrm{O}_{2-}\right.$ ${ }_{\delta}-1000$ with $0<\mathrm{x}<1$ ), compared to the conversion curve of pure oxide $\mathrm{CeO}_{2}-1000$, in both $\mathrm{NOx} / \mathrm{O}_{2}$ 
and $\mathrm{O}_{2} / \mathrm{N}_{2}$ atmospheres, with the greatest difference among $\mathrm{CeO}_{2}-1000$ and the praseodymiumcontaining catalysts when the atmosphere contains NOx. This can be ascribed to the higher $\mathrm{NO}_{2}$ production and the lower temperatures at which takes place, observed in any of the praseodymiumcontaining samples versus pure $\mathrm{CeO}_{2}-1000$.

In Figure 8a, all the $\mathrm{Ce}_{\mathrm{x}} \mathrm{Pr}_{1-\mathrm{x}} \mathrm{O}_{2-\delta}-1000$ oxides, except pure $\mathrm{CeO}_{2}-1000$ oxide, have very similar $\mathrm{T} 50 \%$ values (in the narrow range of $587^{\circ} \mathrm{C}$ to $589^{\circ} \mathrm{C}$, see Table 4). However, for the low temperature range $\left(350-550^{\circ} \mathrm{C}\right)$, in which the soot conversion is less than $25 \%$, the $\mathrm{Ce}_{0.8} \operatorname{Pr}_{0.2} \mathrm{O}_{2-\delta^{-}} 1000$ mixed oxide shows less activity than the other oxides, which is related to its $\mathrm{NO}_{2}$ production in the blank test at higher temperatures range (the $\mathrm{NO}_{2}$ formation profile for $\mathrm{Ce}_{0.8} \mathrm{Pr}_{0.2} \mathrm{O}_{2-\delta}-1000$ starts at temperatures above $350^{\circ} \mathrm{C}$, while the other praseodymium-containing oxides already show $\mathrm{NO}_{2}$ formation from $250^{\circ} \mathrm{C}$ on, Figure $6 b$ ).

Regarding the soot combustion tests under $\mathrm{O}_{2} / \mathrm{N}_{2}$ atmosphere of these $\mathrm{Ce}_{\mathrm{x}} \mathrm{Pr}_{1-\mathrm{x}} \mathrm{O}_{2-\delta}-1000$ oxides, with the exception of pure $\mathrm{CeO}_{2}-1000$ (Figure $8 \mathrm{~b}$ ), the $\mathrm{T} 50 \%$ values remain the same or are slightly worse than those obtained under $\mathrm{NOx} / \mathrm{O}_{2}$ atmosphere, being $\mathrm{PrO}_{2-\delta}-1000$ the one with the highest activity under these conditions, although the differences with the other $\mathrm{Ce}_{\mathrm{x}} \operatorname{Pr}_{1-\mathrm{x}} \mathrm{O}_{2-\delta^{-}} 1000$ mixed oxides are very small. On the other hand, and regarding the $\mathrm{PrO}_{2-\delta}-1000$ oxide, it is important to mention the low selectivity towards the $\mathrm{CO}$ formation under $\mathrm{O}_{2} / \mathrm{N}_{2}(3 \%$, Table 4$)$, which certifies that this oxide, even when calcined at $1000^{\circ} \mathrm{C}$, presents a considerable activity as an oxidation catalyst, since its high activity in the $\mathrm{NO}$ oxidation to $\mathrm{NO}_{2}$ has already revealed (Figure 6b).

\section{Conclusions}

In this work, catalysts with different $\mathrm{Ce}_{\mathrm{x}} \operatorname{Pr}_{1-\mathrm{x}} \mathrm{O}_{2-\delta}$ composition (with $0<\mathrm{x}<1$ ) have been prepared using the co-precipitation method, calcining these oxides at both $500^{\circ} \mathrm{C}$ and $1000^{\circ} \mathrm{C}$. After performing soot combustion tests, the $\mathrm{Ce}_{0.5} \mathrm{Pr}_{0.5} \mathrm{O}_{2-\delta}$ composition showed a high catalytic performance under $\mathrm{NOx} / \mathrm{O}_{2}$. Therefore, this formulation has also been synthesized by a simple method, consisting of calcining the precursor nitrates at $500^{\circ} \mathrm{C}$. The structural and surface characterization of these oxides and the catalytic activity evaluation of soot combustion under both $\mathrm{NOx} / \mathrm{O}_{2}$ and $\mathrm{O}_{2} / \mathrm{N}_{2}$ atmospheres, and in the $\mathrm{NO}$ oxidation to $\mathrm{NO}_{2}$ as well have led to the following conclusions: 
As the nominal praseodymium content of the $\mathrm{Ce}_{\mathrm{x}} \mathrm{Pr}_{1-\mathrm{x}} \mathrm{O}_{2-\delta}$ mixed oxide increases, a part of this Pr doping is inserted into the ceria lattice, but another part is segregated onto the surface of the particles. Due to this, all the $\mathrm{Ce}_{\mathrm{x}} \mathrm{Pr}_{1-\mathrm{x}} \mathrm{O}_{2-\delta}-\mathrm{T}$ mixed oxides present superficial praseodymium enrichment, even obtaining a clear phase segregation in the case of $\mathrm{Ce}_{0.2} \mathrm{Pr}_{0.8} \mathrm{O}_{2-\delta}$ when it is calcined at $1000^{\circ} \mathrm{C}$.

Regarding the $\mathrm{Ce}_{\mathrm{x}} \mathrm{Pr}_{1-\mathrm{x}} \mathrm{O}_{2-\delta}-500$ mixed oxides, part of the praseodymium that is inserted into the ceria lattice is present as $\operatorname{Pr}^{3+}$, which leads to the presence of a significant number of anionic vacancies in this oxide. However, when these mixed oxides are calcined at $1000^{\circ} \mathrm{C}$, the $\mathrm{Pr}^{3+}$ proportion inserted into the structure of the ceria decreases. On the other hand, the calcination at $1000^{\circ} \mathrm{C}$ of pure $\mathrm{PrO}_{2-\delta}$ leads to a higher $\mathrm{Pr}^{3+}$ presence than its counterpart calcined at $500^{\circ} \mathrm{C}$.

The $\mathrm{Ce}_{0.5} \mathrm{Pr}_{0.5} \mathrm{O}_{2-\delta}$ composition calcined at $500^{\circ} \mathrm{C}$ presents higher praseodymium enrichment on the particles surface when using the nitrate calcination method compared to the co-precipitation method, which implies a lower insertion of the doping cation into the structure of the ceria.

The ceria doping with praseodymium leads to a better reduction of the oxide, with the reduction profiles moving towards lower temperatures compared to pure ceria. Additionally, a higher $\mathrm{NO}$ oxidation capacity to $\mathrm{NO}_{2}$ is observed after $\mathrm{Pr}$ doping. In both cases, the pure $\mathrm{PrO}_{2-\delta}$ showed the best behavior.

The $\mathrm{Ce}_{0.5} \mathrm{Pr}_{0.5} \mathrm{O}_{2-\delta}-500$ composition exhibits the highest catalytic activity in soot combustion. Under $\mathrm{NOx} / \mathrm{O}_{2}$ atmosphere, this oxide is most active one when prepared by nitrate calcination. However, under $\mathrm{O}_{2} / \mathrm{N}_{2}$ atmosphere a better activity is achieved if the co-precipitation method is used, because under these reaction conditions, a better praseodymium insertion into the ceria lattice seems to lead to an improved oxygen mobility both on the surface and in the oxide framework.

\section{Acknowledgements}


The authors gratefully acknowledge the financial support of Generalitat Valenciana (PROMETEO/2018/076 project) and the Spanish Ministry of Economy and Competitiveness (CTQ2015-64801-R project) and the UE-FEDER funding. J.C.M.M. also acknowledges Spanish Ministry of Science, Innovation and Universities for the financial support through a FPU grant (FPU17/00603). 


\section{References}

[1] J. Kašpar, P. Fornasiero, N. Hickey, Catal. Today 77 (2003) 419-449.

[2] J.P.A. Neeft, M. Makkee, J.A. Moulijn, Fuel Process. Technol. 47 (1996) 1-69.

[3] B. Stanmore, J.. Brilhac, P. Gilot, Carbon N. Y. 39 (2001) 2247-2268.

[4] B.A.A.L. van Setten, J.M. Schouten, M. Makkee, J. a. Moulijn, Appl. Catal. B Environ. 28 (2000) 253-257.

[5] M. V. Twigg, Catal. Today 163 (2011) 33-41.

[6] D. Fino, S. Bensaid, M. Piumetti, N. Russo, Appl. Catal. A Gen. 509 (2016) 75-96.

[7] P. Forzatti, L. Lietti, L. Castoldi, Catal. Letters 145 (2015) 483-504.

[8] T. Johnson, Platin. Met. Rev. 52 (2008) 23-37.

[9] I. Atribak, A. Bueno-López, A. García-García, Top. Catal. 52 (2009) 2088-2091.

[10] N. Guillén-Hurtado, A. García-García , A. Bueno-López, Appl. Catal. B. 174-175 (2015) 6066.

[11] M. Shelef, R.W. McCabe, Catal. Today 62 (2005) 35-50.

[12] J. Kašpar, P. Fornasiero, J. Solid State Chem. 171 (2003) 19-29.

[13] T. Bunluesin, R.J. Gorte, G.W. Graham, Appl. Catal. B 14 (1997) 105-115.

[14] I. Atribak, I. Such-Basáñez, A. Bueno-López, A. García-García, J. Catal. 250 (2007) 75-84.

[15] T. Murota, T. Hasegawa, S. Aozasa, H. Matsui, M. Motoyama, J. Alloy. Compd. 193 (1993) 298-299.

[16] E. Mamontov, T. Egami, R. Brezny, M. Koranne, S. Tyagi, J. Phys. Chem. B 104 (2000) 11110-11116.

[17] M.A. Malecka, L. Kepinski, W. Mista, Appl. Catal. B 74 (2007) 290-298.

[18] I. Atribak, A. Bueno-López, A. García-García, J. Mol. Catal. A: Chem. 300 (2009) 103-110.

[19] K. Krishna, A. Bueno-López, M. Makkee, J.A. Moulijn, Appl. Catal. B 75 (2007) 189-200.

[20] T. Miki, T. Ogawa, M. Haneda, N. Kakuta, A. Ueno, S. Tateishi, S. Matsuura, M. Sato, J. Phys. Chem. 94 (1990) 6464-6467.

[21] E. Aneggi, C. de Leitenburg, A. Trovarelli, Catal. Today 181 (2012) 108-115.

[22] S. Damyanova, B. Pawelec, K. Arishtirova, M.V. Martinez Huerta, J.L.G. Fierro, Appl. Catal. A 337 (2008) 86-96.

[23] I. Atribak, A. Bueno-López, A. García-García, Catal. Commun. 9 (2008) 250-255.

[24] W.Y. Hernández, M.A. Centeno, F. Romero-Sarria, J.A. Odriozola, J. Phys. Chem. C 113 (2009) 5629-5635.

[25] A. Bueno-López, K. Krishna, M. Makkee, J.A. Moulijn, J. Catal. 230 (2005) 237-248.

[26] R.V. Mangalaraja, S. Ananthakumar, K. Uma, R.M. Jiménez, S Uthayakumar, M. López, C.P. Camurri, J. Ceram. Process. Res. 13 (2012) 15-22.

[27] B.M. Reddy, P. Bharali, P. Saikia, A. Khan, S. Loridant, M. Muhelr, W. Grünert, J. Phys. Chem. C 111 (2007) 1878-1881. 
[28] A.K. Shina, K. Suzuki, J. Phys. Chem. B 109 (2005) 1708-1714.

[29] A. Trovarelli, Catalysis by Ceria and Related Materials, Catalytic Science Series, Vol. 2, Imperial College Press (2002).

[30] P. Fornasiero, R. Di Monte, G. Ranga Rao, J. Kaspar, S. Meriani, A. Trovarelli, M. Graziani, J. Catal. 151 (1995) 168-177.

[31] F. Zamar, A. Trovarelli, C. de Leitenburg, G. Dolcetti, J. Chem. Soc. Chem. Comm. 9 (1995) 965-966.

[32] M. Boaro, C. de Leitenburg, G. Dolcetti, A. Trovarelli, J. Catal. 193 (2000) 338-347.

[33] B.M. Reddy, P. Saikia, P. Bharali, Y. Yamada, T. Kodayashi, M. Muhler, W. Grünert, J. Phys. Chem. C 112 (2008) 16393-16399.

[34] B.M. Reddy, G. Thrimurthulu, L. Katta, Y. Yamada, S.E. Park, J. Phys. Chem. C 113 (2009) 15882-15890.

[35] A.D. Logan, M. Shelef, J. Mater. Res. 9 (1994) 468-475.

[36] H. Borchert, Y.V. Frolova, V.V. Kaichev, I.P. Prosvirin, G.M. Alikina, A.I. Lukashevich, V.I. Zaikovskii, E.M. Moroz, S.N. Trukhan, V.P. Ivanov, E.A. Paukshtis, V.I. Bukhtiyarov, V.A. Sadykov, J. Phys. Chem. B 109 (2005) 5728-5738.

[37] S. Somacescu, V. Parvulescu, J.M. Calderon-Moreno, S.-H. Suh, P. Osiceanu, B.-L. Su, J. Nanopart. Res. 14 (2012) 1-17.

[38] M.Y. Sinev, G.W. Graham, L.P. Haack, M. Shelef, J. Mate. Res. 11 (1996) 1960-1971.

[39] G. Zhang, Z. Zhao, J. Xu, J. Zheng, J. Liu, G. Jiang, A. Duan, H. He, Appl. Catal. B 107 (2011) 302-315.

[40] W. Huang, P. Shuk, M. Greenblatt, Solid State Ionics 113-115 (1998) 305-310.

[41] N.N. Greenwood, A. Earnshaw, Chemistry of the Elements, Second Edition, Elsevier Butterworth-Heinemann (1997).

[42] J.A. Rodriguez, X. Wang, J.C. Hanson, G. Liu, A. Iglesias-Juez, M.J. Fernandez-Garcia, J. Phys. Chem. B 107 (2003) 3535-3543.

[43] X. Wang, J.C. Hanson, G. Liu, J.A. Rodriguez, A. Iglesias-Juez, M. Fernández-García, J. Chem. Phys. 121 (2004) 5434-5444.

[44] K.M. Ryan, J.P. McGrath, R.A. Farell, W.M. O’Neill. C.J. Barnes, M.A. Morris, J. Phys.: Condens. Matter 15 (2003) L49-L58.

[45] A. Hartridge, M.G. Krishna, A.K. Bhattacharya, Mater. Sci. Eng. B 57 (1999) 173-178.

[46] B. de Rivas, N. Guillén-Hurtado, R. López-Fonseca, F. Coloma-Pascual, A. García-García, J.I. Gutiérrez-Ortiz, A. Bueno-López, Appl. Catal. B 121-122 (2012) 162-170.

[47] K. Krishna, A. Bueno-López, M. Makkee, J.A. Molijn, Appl. Catal. B 75 (2007) 210-220.

[48] A. Davó-Quiñonero, J. González-Mira, D. Lozano-Castelló, A. Bueno-López, Catal. Letters, 148 (2018) 258-266.

[49] J. Giménez-Mañogil, N. Guillén-Hurtado, S. Fernández-García, X. Chen, J.J. CalvinoGámez, A. García-García, Top. Catal. 59 (2016) 1065-1070.

[50] I. Popescu, J.C. Martínez-Munuera, A. García-García, I.C. Marcu, Appl. Catal. A 578 (2019) 
30-39.

[51] J.C. Martínez-Munuera, M. Zoccoli, J. Giménez-Mañogil, A. García-García, Appl. Catal. B 245 (2019) 706-720.

[52] V. Rico-Pérez, E. Aneggi, A. Bueno-López, A. Trovarelli, Appl. Catal. B 197 (2016) 95104.

[53] T. Andana, M. Piumetti, S. Bensaid, L. Veyreb, C. Thieuleux, N. Russo, D. Fino, E. A. Quadrelli, R. Pirone, Appl. Catal. B, 226 (2018) 147-161.

[54] T. Andana, M. Piumetti, S. Bensaid, N. Russo, D. Fino, R. Pirone, Appl. Catal. B, 197 (2016) $125-137$.

[55] E. J. Jeong, J.H. Lee, S. H. Lee, C. S. Park, J. W. Choung, C. H. Kim, K.Y. Lee, ChemCatChem 11 (2019) 2131-2141.

[56] N. Guillén-Hurtado, A. Bueno-López, A. García-García, J. Mater. Sci. 47 (2012) 3204-3213.

[57] N. Guillén-Hurtado, A. Bueno-López, A. García-García, Appl. Catal. A 437-438 (2012) 166172.

[58] D. Terribile, A. Trovarelli, J. Llorca, C. de Leitenburg, G. Dolcetti, Catal. Today 43 (1998) 79-88.

[59] M. Rajendran, K.K. Mallick, A.K. Bhattacharya, J. Mater. Sci. 33 (1998) 5001-5006.

[60] M.F. Luo, Z.L. Yan, L.Y. Jin, J. Mol. Catal. A: Chem. 260 (2006) 157-162.

[61] S. Rossignol, C. Descorme, C. Kappenstein, D. Duprez, J. Mater. Chem. 11 (2001) $2587-$ 2592 .

[62] M.P. Yeste Sigüenza, PhD Thesis, University of Cádiz (2009).

[63] R.D. Shannon, C.T. Prewitt, Acta Crystallogr. 32A (1976) 751-767.

[64] S. Bernal, G. Blanco, M.A. Cauqui, A. Martín, J.M. Pintado, A. Galtayries, R. Sporken, Surf. Interf. Anal. 30 (2000) 85-89.

[65] P. Shuk, M. Greenblatt, Solid State Ionics 116 (1999) 217-223.

[66] A.R. West, Solid State Chemistry and its Applications, Ed. John Wiley and Sons (1995).

[67] Y. Takasu, T. Sugino, Y. Matsuda, J. Appl. Electrochem. 14 (1984) 79-81.

[68] A.E. Sovestnov, V.A. Shaburov, B.T. Melekh, I.A. Smirnov, Y.P. Smirnov, A.V. Tyunis, A.I. Egorov, Phys. Solid State 36 (1994) 620-624.

[69] F. Zhang, C.H. Chen, J.C. Hanson, R.D. Robinson, I.P. Herman, S.W. Chan, J. Amer. Ceram. Soc. 89 (2006) 1028-1036.

[70] J.R. McBride, K.C. Hass, B.D. Poindexter, W.H. Weber, J. Appl. Phys. 76 (1994) 24352441.

[71] V.G. Keramidas, W.B. White, J. Chem. Phys. 59 (1973) 1561-1562.

[72] Y. Ito, Y. Lei, N.D. Browning, T.J. Mazanec, Mater. Res. Soc. Symp. Proc. 703 (2002) 489494.

[73] P. Knauth, H.L. Tuller, Mater. Res. Soc. Symp. Proc. 548 (1999) 429-442.

[74] M. Ozawa, R. Onoe, H. Kato, J. Alloy. Compd. 408-412 (2006) 556-559. 
[75] S. Letichevsky, C.A. Tellez, R.R. de Avillez, M.I.P. da Silva, M.A. Fraga, L.G. Appel, Appl. Catal. B 58 (2005) 203-210.

[76] I. Atribak, F.E. López-Suárez, A. Bueno-López, A. García-García, Catal. Today 176 (2011) 404-408.

[77] Handbook of Chemistry and Physics, edited by D.R. Lade, CRC Press, $75^{\text {th }}$ ed. (1994-1995).

[78] Z.Y Pu, X.S. Liu, A.P. Jia, Y.L. Xie, J.Q. Lu, M.F. Luo, J. Phys. Chem. C 112 (2008) 1504515051. 


\section{LIST OF TABLES}

Table 1. BET surface area and apparent cubic cell parameter of the $\mathrm{Ce}_{\mathrm{x}} \mathrm{Pr}_{1-\mathrm{x}} \mathrm{O}_{2-\delta}$-T oxides.

\begin{tabular}{ccc}
\hline Sample & $\begin{array}{c}\text { BET surface } \\
\text { area }\left(\mathbf{m}^{2} / \mathbf{g}\right)\end{array}$ & $\begin{array}{c}\text { Apparent } \boldsymbol{a}(\mathbf{n m}) \\
\text { Cell parameter }\end{array}$ \\
\hline $\mathrm{CeO}_{2}-500$ & 54 & 0.5415 \\
$\mathrm{CeO}_{2}-1000$ & 1 & 0.5424 \\
$\mathrm{Ce}_{0.8} \mathrm{Pr}_{0.2} \mathrm{O}_{2-\delta}-500$ & 67 & 0.5424 \\
$\mathrm{Ce}_{0.8} \mathrm{Pr}_{0.2} \mathrm{O}_{2-\delta}-1000$ & 4 & 0.5406 \\
$\mathrm{Ce}_{0.5} \mathrm{Pr}_{0.5} \mathrm{O}_{2-\delta}-500$ & 28 & 0.5433 \\
$\mathrm{Ce}_{0.5} \operatorname{Pr}_{0.5} \mathrm{O}_{2-\delta}-500-\mathrm{CAL}$ & 37 & 0.5424 \\
$\mathrm{Ce}_{0.5} \mathrm{Pr}_{0.5} \mathrm{O}_{2-\delta}-1000$ & 3 & 0.5406 \\
$\mathrm{CeO}_{2}(\mathrm{JCPDS} 34-0394)$ & & 0.5411 \\
$\mathrm{PrO}_{2}(\mathrm{JCPDS} 24-1006)$ & & 0.5391 \\
$\mathrm{Pr}_{6} \mathrm{O}_{11}(\mathrm{JCPDS} 42-1121)$ & & 0.5470 \\
$\mathrm{PrO}_{1.83}(\mathrm{JCPDS} 06-0329)$ & & 0.5466
\end{tabular}

${ }^{a}$ Experiental cubic cell parameter estimated from peak (111). They are named as "apparent" because no diffractogram refinement technique was used for their calculation.

Table 2. Ionic radii of the cerium and praseodymium cations with coordination number eight

[63].

\begin{tabular}{cc}
\hline Cation & Radius $(\mathbf{n m})$ \\
\hline $\mathbf{C e}^{4+}$ & 0.097 \\
$\mathbf{P r}^{4+}$ & 0.096 \\
$\mathbf{C e}^{3+}$ & 0.1143 \\
$\mathbf{P r}^{3+}$ & 0.1126
\end{tabular}


Table 3. Surface atomic concentrations and surface atomic ratios estimated by XPS for $\mathrm{Ce}_{x} \operatorname{Pr}_{1-}$ $\mathrm{x}_{2-\delta}-\mathrm{T}$.

\begin{tabular}{|c|c|c|c|c|c|c|c|}
\hline \multirow[t]{2}{*}{ Sample } & \multicolumn{4}{|c|}{$\begin{array}{c}\text { Surface atomic } \\
\text { concentrations (atomic \%) }\end{array}$} & \multicolumn{3}{|c|}{ Surface atomic ratios } \\
\hline & $\mathrm{Ce}$ & $\operatorname{Pr}$ & O & C & $\mathrm{Ce} / \mathbf{P r}^{\mathrm{a}}$ & $\mathrm{Ce}^{3+}(\%)^{\mathrm{b}}$ & $\operatorname{Pr}^{3+}(\%)^{c}$ \\
\hline $\mathrm{CeO}_{2}-500$ & 15.4 & - & 55.9 & 28.7 & - & 28.2 & - \\
\hline $\mathrm{CeO}_{2}-1000$ & 7.9 & - & 45.4 & 46.7 & - & 32.1 & - \\
\hline $\mathrm{Ce}_{0.8} \mathrm{Pr}_{0.2} \mathrm{O}_{2-\delta}-500$ & 11.0 & 6.8 & 42.1 & 40.1 & $1.6(4.0)$ & 33.5 & 58.3 \\
\hline $\mathrm{Ce}_{0.8} \mathrm{Pr}_{0.2} \mathrm{O}_{2-\delta}-1000$ & 10.7 & 8.7 & 37.3 & 43.3 & $1.2(4.0)$ & 41.4 & 57.0 \\
\hline $\mathrm{Ce}_{0.5} \mathrm{Pr}_{0.5} \mathrm{O}_{2-\delta}-500$ & 5.9 & 10.6 & 32.2 & 51.3 & $0.5(1.0)$ & 36.0 & 68.2 \\
\hline $\mathrm{Ce}_{0.5} \mathrm{Pr}_{0.5} \mathrm{O}_{2-\delta}-500-\mathrm{CAL}$ & 4.2 & 10.4 & 34.5 & 50.9 & $0.4(1.0)$ & 31.0 & 70.5 \\
\hline $\mathrm{Ce}_{0.5} \mathrm{Pr}_{0.5} \mathrm{O}_{2-\delta}-1000$ & 4.4 & 10.9 & 31.3 & 53.4 & $0.4(1.0)$ & 37.3 & 53.5 \\
\hline $\mathrm{Ce}_{0.2} \mathrm{Pr}_{0.8} \mathrm{O}_{2-\delta_{-}} 500$ & 2.8 & 19.7 & 46.8 & 30.7 & $0.14(0.25)$ & 32.2 & 42.2 \\
\hline $\mathrm{Ce}_{0.2} \mathrm{Pr}_{0.8} \mathrm{O}_{2-\delta}-1000$ & 1.7 & 18.1 & 48.1 & 32.1 & $0.09(0.25)$ & 33.4 & 41.2 \\
\hline $\mathrm{PrO}_{2-\delta}-500$ & - & 19.9 & 49.8 & 30.3 & - & - & 35.3 \\
\hline $\mathrm{PrO}_{2-\delta}-1000$ & - & 18.7 & 52.3 & 29.0 & - & - & 61.9 \\
\hline
\end{tabular}

${ }^{a}$ Nominal $\mathrm{Ce} / \mathrm{Pr}$ atomic ratio in parentheses.

${ }^{b} \mathrm{Ce}^{3+}$ percentage with respect to the total cerium amount on surface $\left(100 \cdot \mathrm{Ce}^{3+} /\left(\mathrm{Ce}^{3+}+\mathrm{Ce}^{4+}\right)\right)$.

${ }^{\mathrm{c}} \mathrm{Pr}^{3+}$ percentage with respect to the total praseodymium amount on surface $\left(100 \cdot \mathrm{Pr}^{3+} /\left(\mathrm{Pr}^{3+}+\mathrm{Pr}^{4+}\right)\right)$.

Table 4. $\mathrm{Ce}_{\mathrm{x}} \mathrm{Pr}_{1-\mathrm{x}} \mathrm{O}_{2-\delta}-\mathrm{T}$ oxides: Temperature to reach the $50 \%$ of soot conversion $\left(\mathrm{T} 50 \%\left({ }^{\circ} \mathrm{C}\right)\right)$ and real selectivity towards $\mathrm{CO}$ formation (\%), both under $\mathrm{NOx} / \mathrm{O}_{2}$ and $\mathrm{O}_{2} / \mathrm{N}_{2}$ atmospheres.

\begin{tabular}{|c|c|c|c|c|}
\hline Sample & $\begin{array}{c}\text { T50\% }\left({ }^{\circ} \mathrm{C}\right) \\
\text { NOx/O }\end{array}$ & $\begin{array}{c}\mathrm{T50} \%\left({ }^{\circ} \mathrm{C}\right) \\
\mathrm{O}_{2} / \mathrm{N}_{2}\end{array}$ & $\begin{array}{c}\text { Real selectivity to } \\
\mathrm{CO}(\%) \text { under } \\
\mathrm{NOx} / \mathrm{O}_{2}\end{array}$ & $\begin{array}{c}\text { Real selectivity to } \\
\mathrm{CO}(\%) \text { under } \\
\mathrm{O}_{2} / \mathrm{N}_{2}\end{array}$ \\
\hline Without catalyst & 603 & 597 & 63 & 60 \\
\hline $\mathrm{CeO}_{2}-500$ & 501 & 580 & 7 & 1 \\
\hline $\mathrm{CeO}_{2}-1000$ & 602 & 594 & 61 & 53 \\
\hline $\mathrm{Ce}_{0.8} \mathrm{Pr}_{0.2} \mathrm{O}_{2-\delta}-500$ & 502 & 547 & 6 & $<1$ \\
\hline $\mathrm{Ce}_{0.8} \mathrm{Pr}_{0.2} \mathrm{O}_{2-\delta}-1000$ & 589 & 589 & 60 & 44 \\
\hline $\mathrm{Ce}_{0.5} \operatorname{Pr}_{0.5} \mathrm{O}_{2-\delta}-500$ & 485 & 542 & 9 & 2 \\
\hline $\mathrm{Ce}_{0.5} \mathrm{Pr}_{0.5} \mathrm{O}_{2-\delta}-500-\mathrm{CAL}$ & 477 & 562 & 10 & $<1$ \\
\hline $\mathrm{Ce}_{0.5} \operatorname{Pr}_{0.5} \mathrm{O}_{2-\delta}-1000$ & 589 & 592 & 60 & 45 \\
\hline $\mathrm{Ce}_{0.2} \mathrm{Pr}_{0.8} \mathrm{O}_{2-\delta}-500$ & 480 & 560 & 16 & 9 \\
\hline
\end{tabular}




\begin{tabular}{ccccc}
$\mathrm{Ce}_{0.2} \mathrm{Pr}_{0.8} \mathrm{O}_{2-\delta}-1000$ & 589 & 592 & 51 & 44 \\
$\mathrm{PrO}_{2-\delta}-500$ & 486 & 560 & 9 & $<1$ \\
$\mathrm{PrO}_{2-\delta}-1000$ & 587 & 586 & 54 & 3 \\
\hline
\end{tabular}

\section{LIST OF FIGURES}

Figure 1. X-Ray diffractograms of $\mathrm{Ce}_{\mathrm{x}} \mathrm{Pr}_{1-\mathrm{x}} \mathrm{O}_{2-\delta}$ (a) calcined at $500^{\circ} \mathrm{C}$ and (b) calcined at $1000^{\circ} \mathrm{C}$, together with representative reference XRD patterns.

Figure 2. Relationship between the apparent cubic cell parameter, presented in Table 1, and the praseodymium atomic content of the $\mathrm{Ce}_{\mathrm{x}} \mathrm{Pr}_{1-\mathrm{x}} \mathrm{O}_{2-\delta}-500$ oxides (blue squares) and $\mathrm{Ce}_{\mathrm{x}} \mathrm{Pr}_{1-\mathrm{x}} \mathrm{O}_{2-\delta}-1000$ (red squares). The dotted lines correspond to equations (2) and (3) derived from Vegard's Law [59].

Figure 3. Raman spectra of the $\mathrm{Ce}_{\mathrm{x}} \mathrm{Pr}_{1-\mathrm{x}} \mathrm{O}_{2-\delta}$ oxides (a) calcined at $500^{\circ} \mathrm{C}$ and (b) calcined at $1000^{\circ} \mathrm{C}$.

Figure 4. Relationship between the position of the maximum Raman $F_{2 g}$ band positions and the Pr atomic percentage in $\mathrm{Ce}_{\mathrm{x}} \operatorname{Pr}_{1-\mathrm{x}} \mathrm{O}_{2-\delta}$ oxides with $0<\mathrm{x}<1$ calcined at $500^{\circ} \mathrm{C}$ (blue circles) and $1000^{\circ} \mathrm{C}$ (red circles). The $\mathrm{Ce}_{0.5} \mathrm{Pr}_{0.5} \mathrm{O}_{2-\delta}-500-\mathrm{CAL}$ mixed oxide is represented with a green square.

Figure 5. $\mathrm{H}_{2}$-TPR profiles of $\mathrm{Ce}_{\mathrm{x}} \operatorname{Pr}_{1-\mathrm{x}} \mathrm{O}_{2-\delta}$ (a) calcined at $500^{\circ} \mathrm{C}$ and (b) calcined at $1000^{\circ} \mathrm{C}$. Both Figures present identical Y-axis scales, for proper comparison.

Figure 6. $\mathrm{NO}_{2}$ formation profiles in blank tests, without soot (under $500 \mathrm{ppm} \mathrm{NOx} / 5 \% \mathrm{O}_{2} / \mathrm{N}_{2}$ ) as a function of temperature, for $\mathrm{Ce}_{x} \mathrm{Pr}_{1-\mathrm{x}} \mathrm{O}_{2-\delta}$ (a) calcined at $500^{\circ} \mathrm{C}$ and (b) calcined at $1000^{\circ} \mathrm{C}$.

Figure 7. Catalytic soot combustion experiments performed with $\mathrm{Ce}_{\mathrm{x}} \mathrm{Pr}_{1-\mathrm{x}} \mathrm{O}_{2-\delta}-500$ (a) in 500 ppm NOx/5\% $\mathrm{O}_{2} / \mathrm{N}_{2}$ atmosphere and (b) in $5 \% \mathrm{O}_{2} / \mathrm{N}_{2}$ atmosphere.

Figure 8. Soot combustion tests for $\mathrm{Ce}_{\mathrm{x}} \mathrm{Pr}_{1-\mathrm{x}} \mathrm{O}_{2-\delta}-1000$ catalysts (a) under $500 \mathrm{ppm} \mathrm{NOx} / 5 \%$ $\mathrm{O}_{2} / \mathrm{N}_{2}$ atmosphere and (b) under $5 \% \mathrm{O}_{2} / \mathrm{N}_{2}$ atmosphere. 

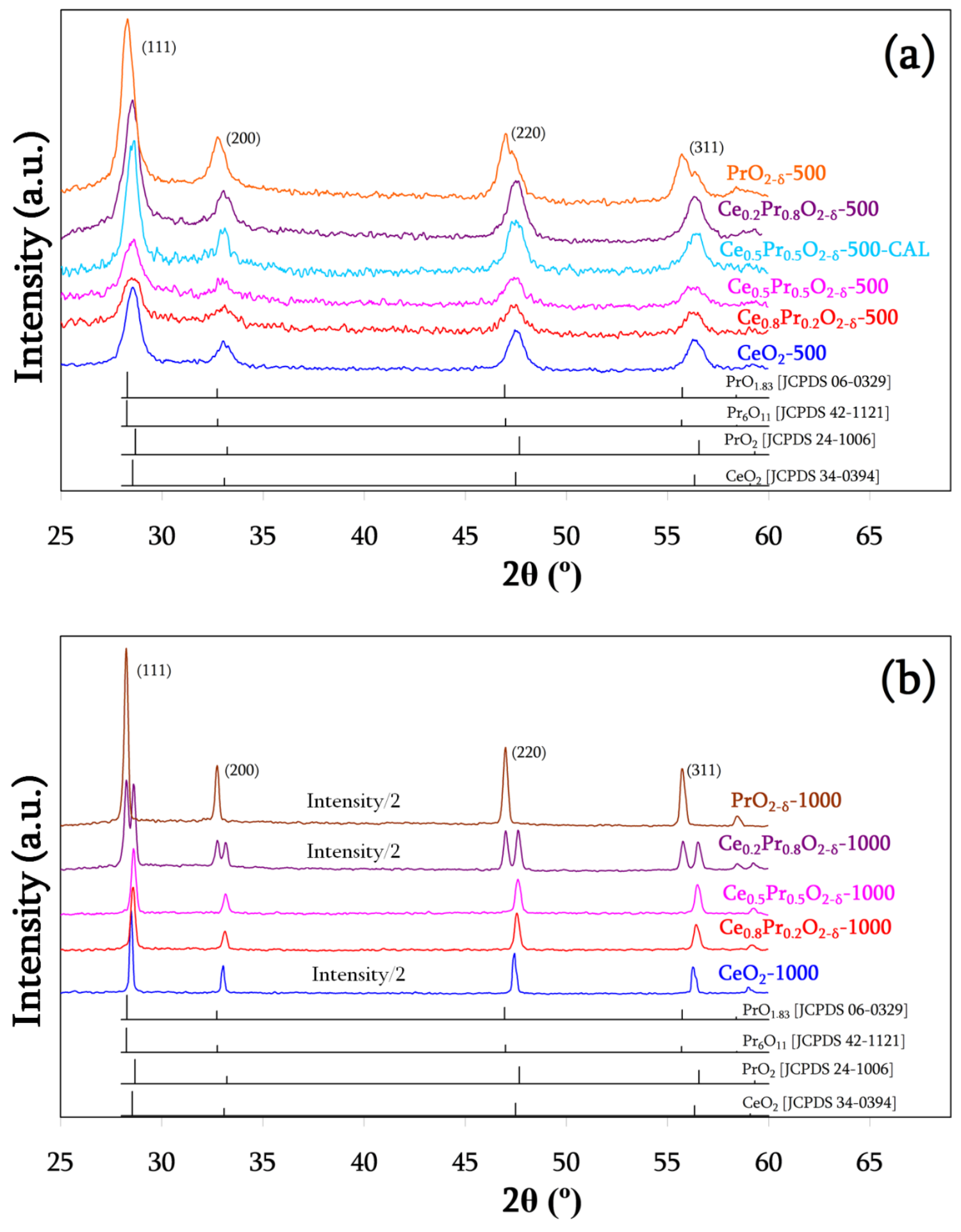

Figure 1. 


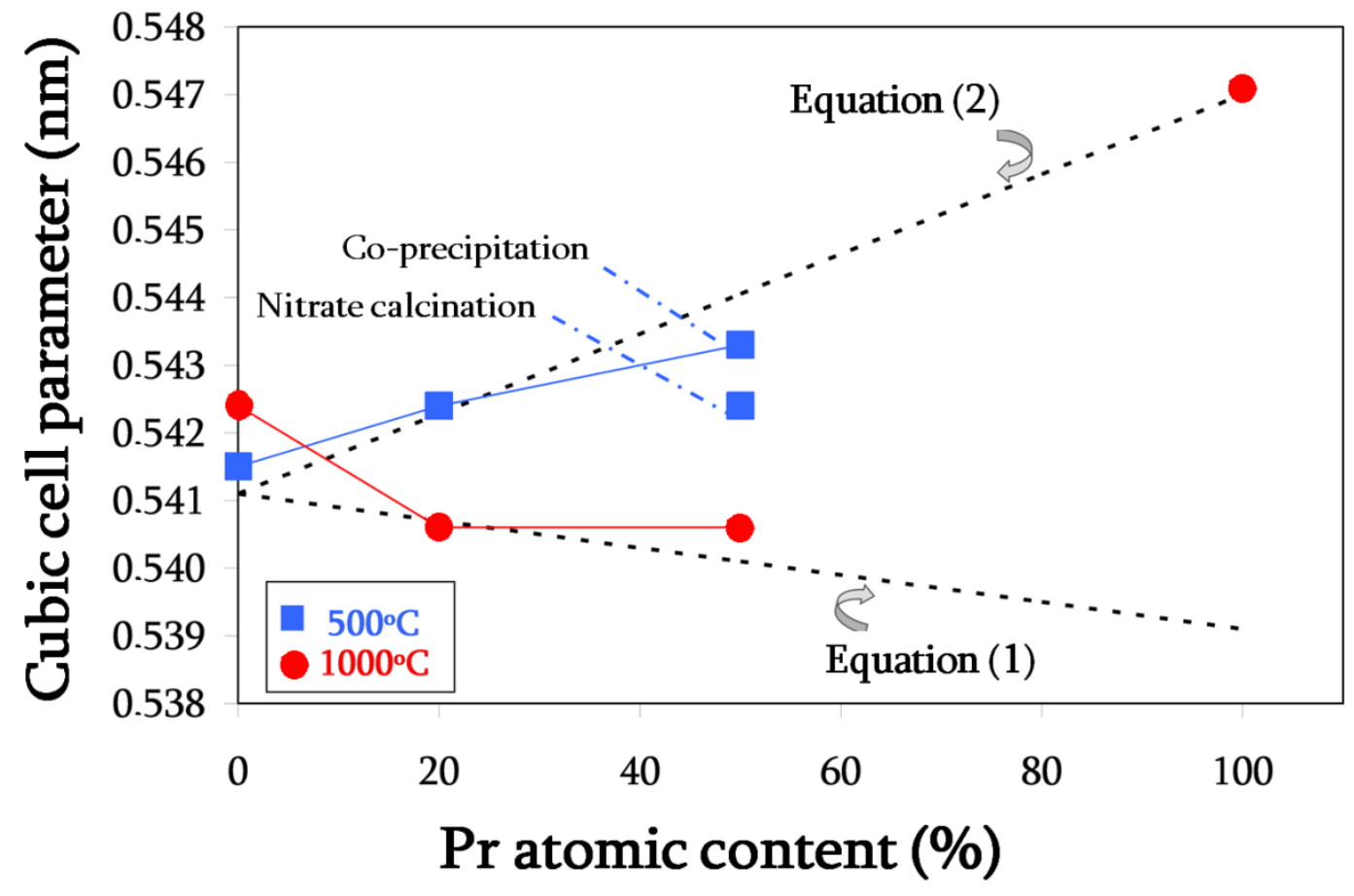

Figure 2. 

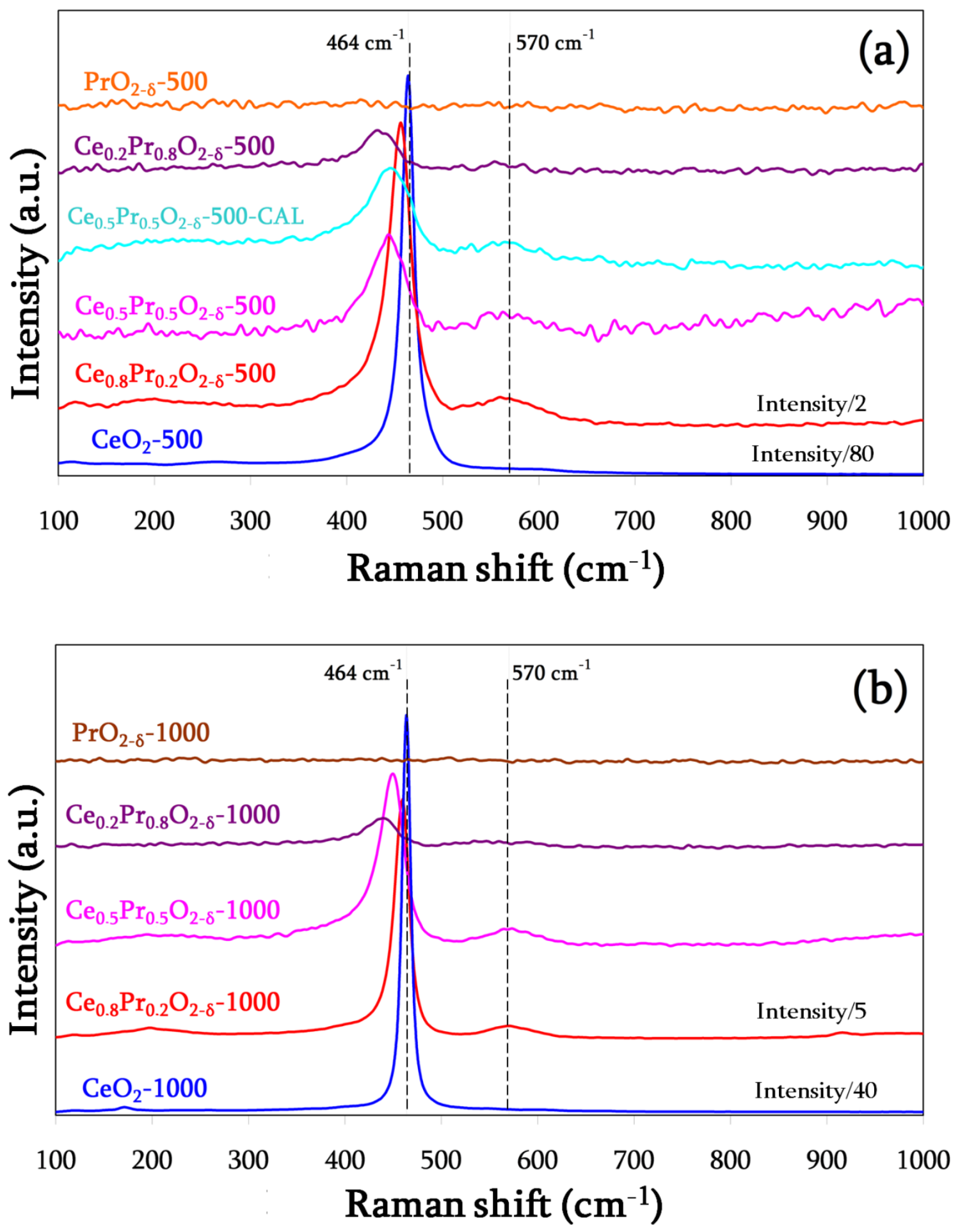


\section{Figure 3.}

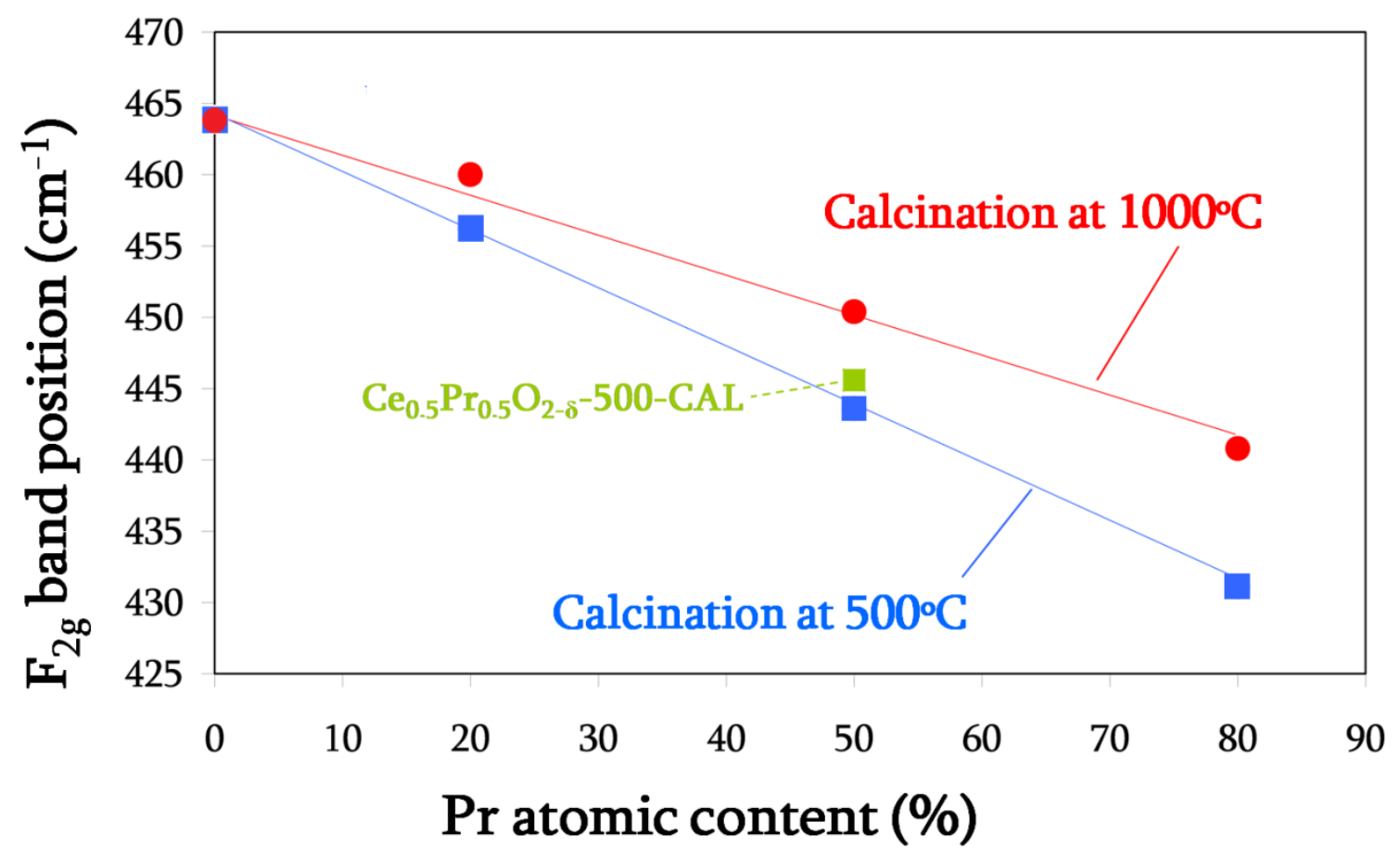

Figure 4. 

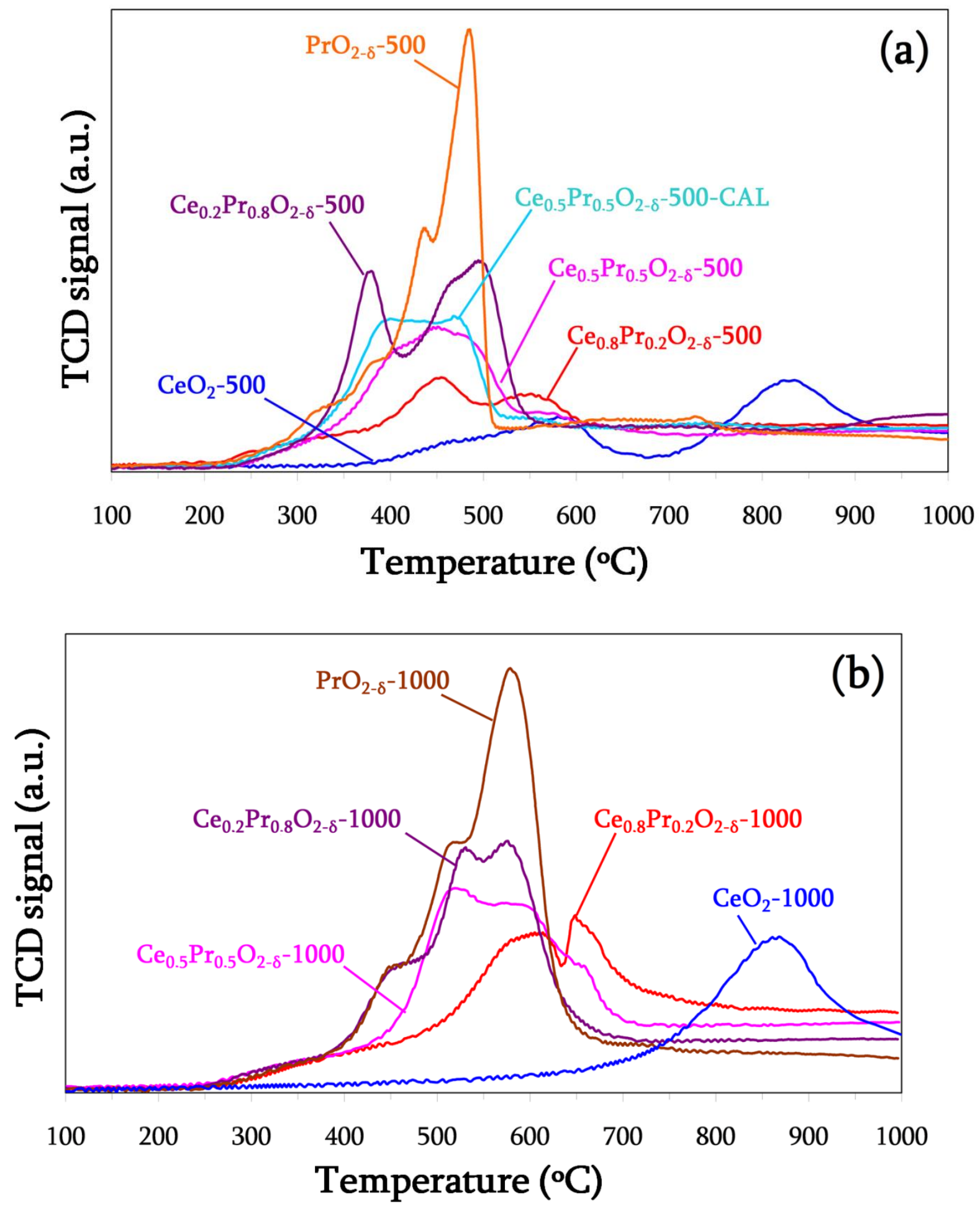

Figure 5. 

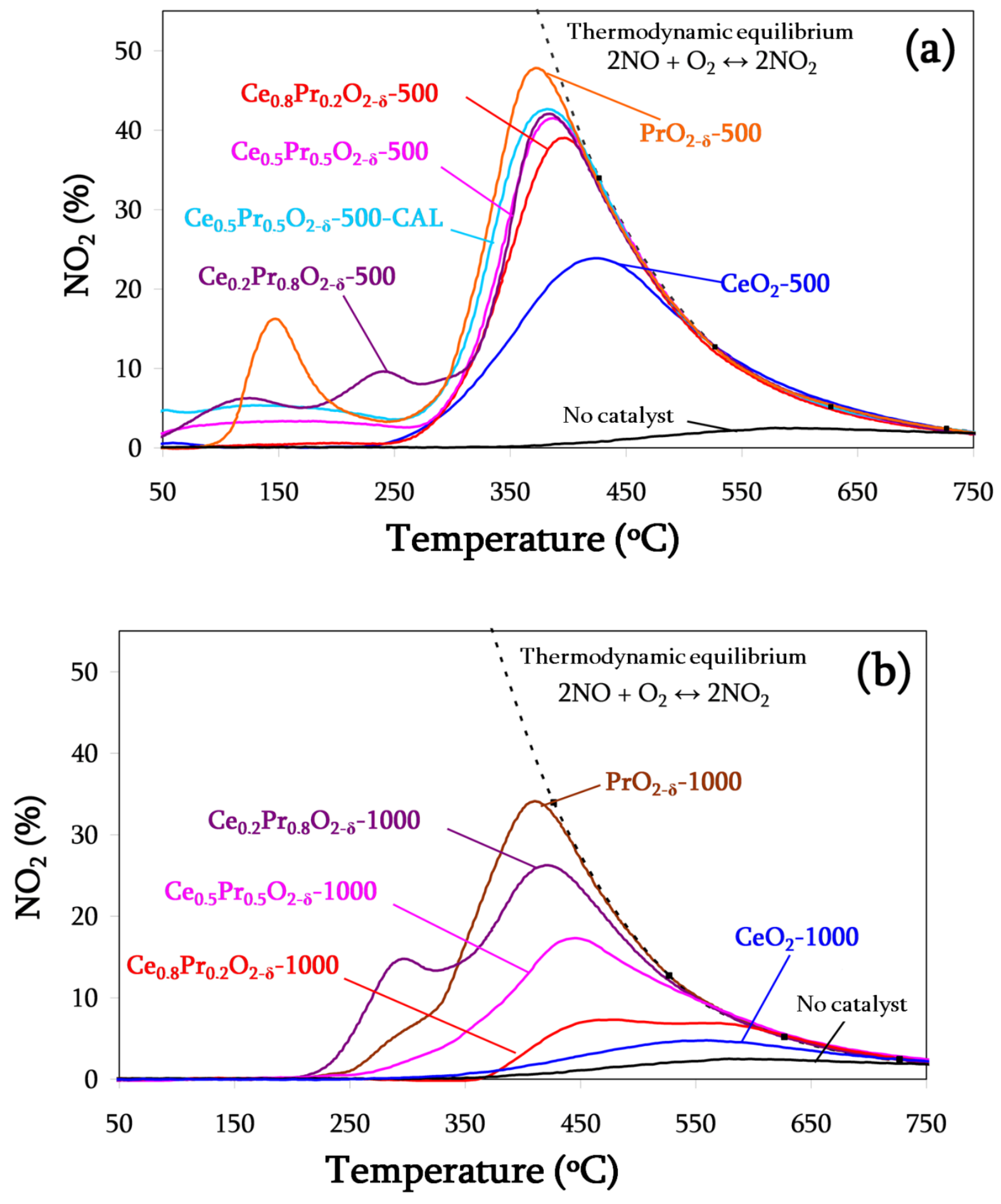

\section{Figure 6.}



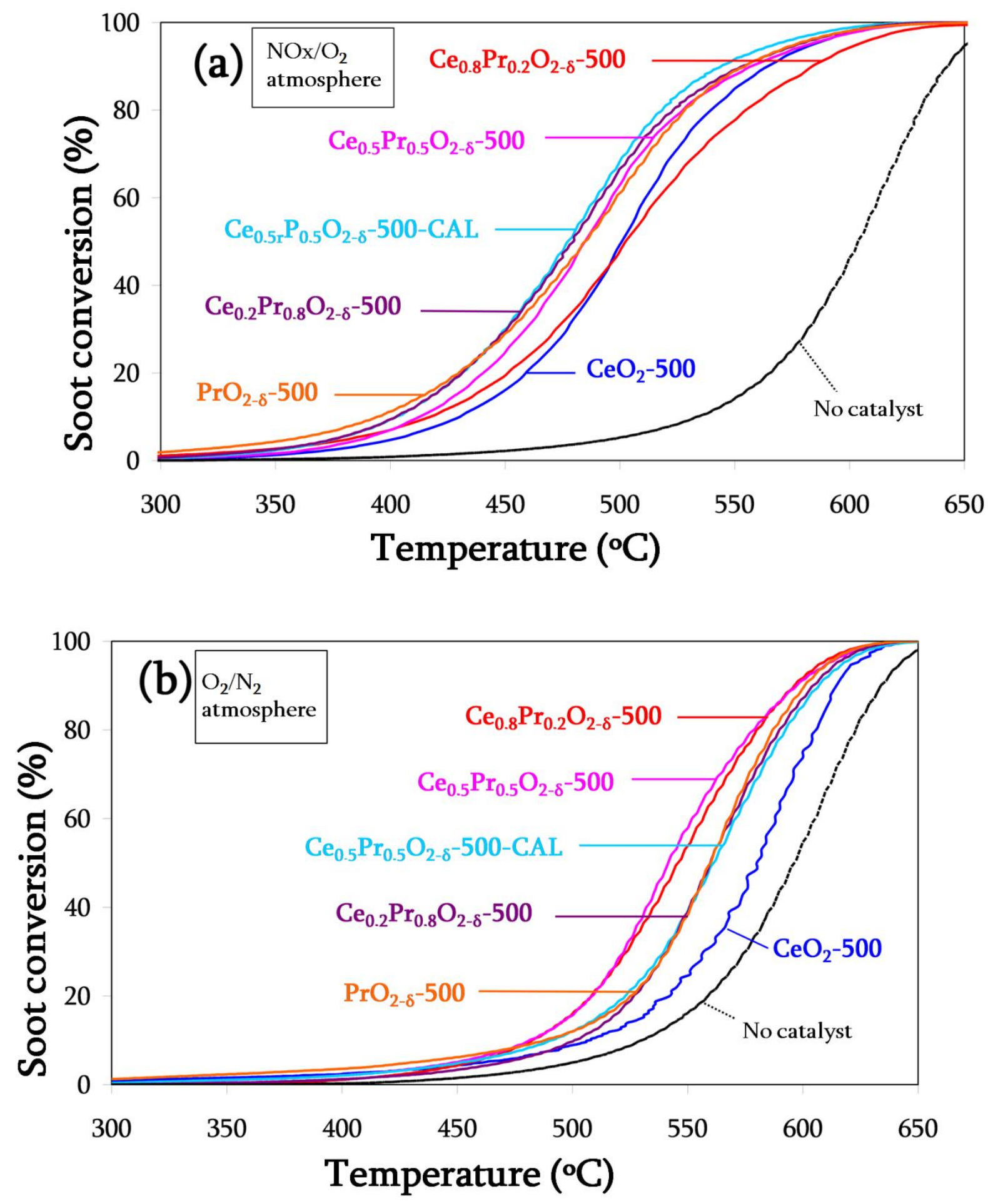

Figure 7. 

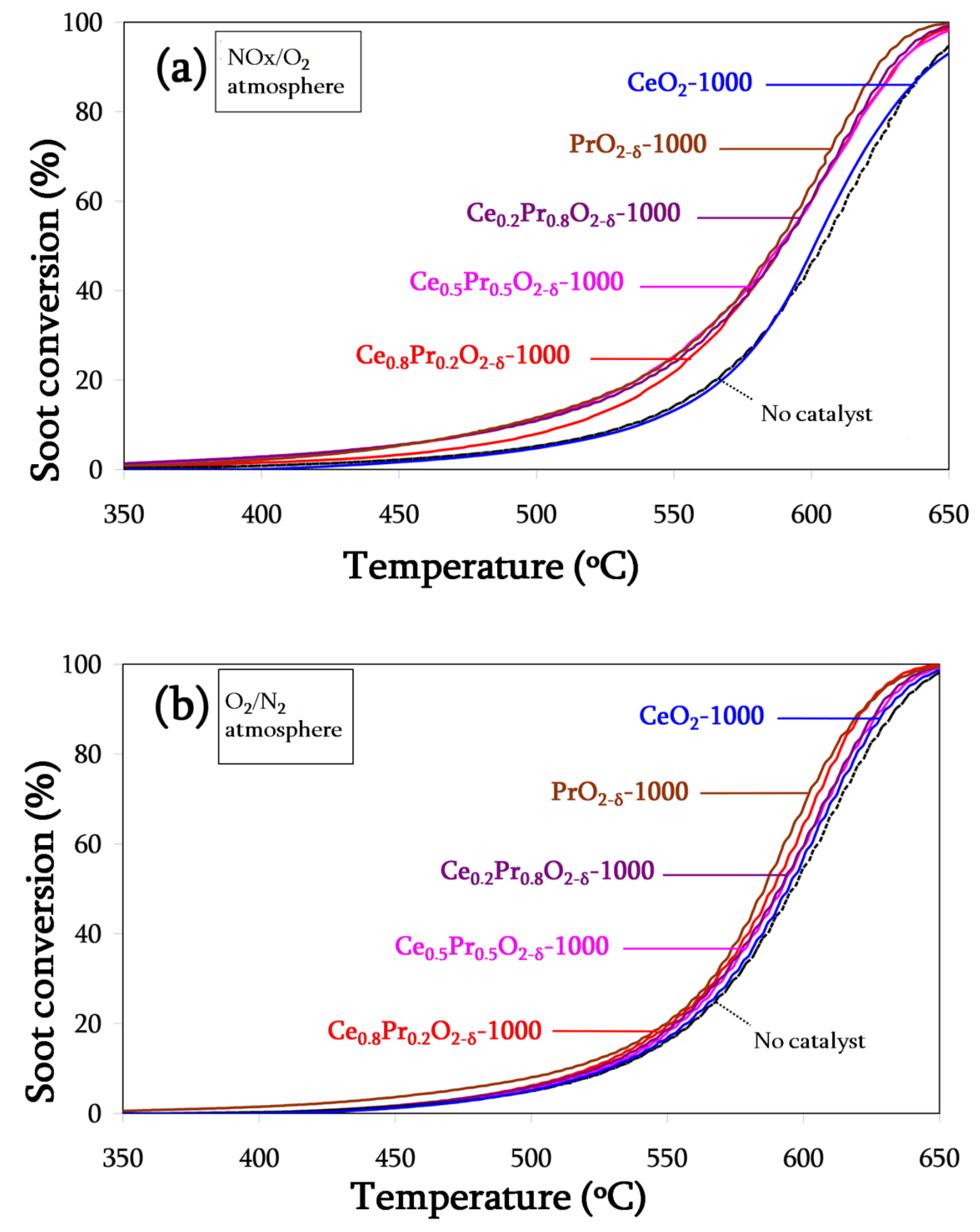

Figure 8. 